\title{
Osmanlı ile Karamanlı Arasında Bir Kadın: İlaldı Hatun
}

\author{
Hamit Şafakci*
}

\begin{abstract}
$\ddot{\mathbf{O}}_{\mathbf{z}}$
İlaldı Hatun, Osmanlı hükümdarı I. Mehmed'in kızıdır. Osmanlı sarayında doğup büyüdükten sonra Karamanoğlu İbrahim Bey'le evlenmiştir. Başka bir deyişle Osmanlı sarayından Karamanlı sarayına gelin gitmiştir. Evliliğin temel nedeni siyasidir. Beylikler arasındaki evlilikler hem ittifakı hem de güçlü olana tabi olmayı ifade ederdi. Buna rağmen anlaşmazlıklar da olabilirdi. İlaldı Hatun, savaşla barış arasında gidip gelen bir kadının öyküsüdür. Zira Karamanoğlu İbrahim Bey ile II. Murad arasındaki savaşlardan sonra arabulucu olmuştur. İlaldı Hatun'un bir diğer özelliği ise onun bir hayırsever olmasıdır. Zira gelirler bıraktığı bir vakıf kurarak hafizların yetiştirilmesini sağlamıştr. 19. yüzylla kadar vakfin var olduğu anlaşılsa da önemini kaybetmesi nedeniyle ortadan kalktığı düşünülmektedir. Ancak kurduğu vakfin kayıtlarda geçmesi bile aşağıda değinileceği üzere tarihi açıdan birçok bilinmezi açığa çıkarmaktadır.
\end{abstract}

Anahtar Kelimeler: Karamanoğlu, Osmanlı, İlaldı Hatun, İbrahim Bey, Çelebi Mehmed.

\section{A Woman Between the Karamanid and the Ottoman: İlaldi Hatun}

\begin{abstract}
Ilaldı Hatun was the daughter of Mehmed I, the Ottoman ruler. She was born and raised in the Ottoman palace, then married to the Karamanid ruler İbrahim Bey. In other words, she was married into the Karamanids palace, leaving the Ottoman palace. The main reason for this marriage was politics. Marriages between the members of principalities referred to alliance between them and being subjected to the strong one. Despite this, there could be disagreements. Illaldı Hatun is the story of a woman who had hovered between war and peace. Because she became a mediator af-

* Doç. Dr., Artvin Çoruh Üniversitesi, Fen Edebiyat Fakültesi, Tarih Bölümü, Artvin/TÜRKIYE, hamitsafakci@artvin.edu.tr ORCID: 0000-0002-1290-3392.

Makale Gönderim Tarihi: 13.07.2018 - Makale Kabul Tarihi: 24.04.2019
\end{abstract}


ter the war between the Karamanid ruler İbrahim Bey and the Ottoman ruler Murad II. In addition, Illaldı Hatun was a philanthropist. Because she established a foundation to train huffath (memorizers of the Quran). Although the foundation has existed until the $19^{\text {th }}$ century, it was abolished because of losing its importance. However, even the existence of her waqf in the historical records reveals many unknowns in terms of history as mentioned below.

Keywords: Karamanids, Ottoman, İlaldı Hatun, İbrahim Bey, Çelebi Mehmed.

\section{Giriş}

Çelebi Mehmed'in kızı olan İlaldı Hatun, Karamanoğlu İbrahim Bey'in eşidir. Bu anlamda hem Osmanlı hem de Karamanlı hanedanına mensup bir kadındır. Çalışmanın başlangıcında İlaldı Hatun'un hayırseverliği dikkati çekmişti. Ancak çalışma ilerleyince konu hakkında farklı görüşlerle ya da bilinmezliklerle örülü bir durumun olduğu anlaşıldı. Bu nedenle konunun öznesi aynı tutulmakla birlikte İlaldı Hatun'un etkileşim halinde olduğu kişilere de değinmek gerektiğinden Çelebi Mehmed, Karamanoğlu İbrahim Bey, İncu Hatun ve Server Ağa gibi şahsiyetlere de kısaca temas edilmiştir ${ }^{1}$. Bu anlamda incelemede; dönemin Osmanlı ve Karamanlı hanedanı, İlaldı Hatun'un hayatı ve eserleri ile Karamanlılarla Osmanlılar arasındaki ilişkiler İlaldı Hatun bağlamında ele alınmıştır.

$\mathrm{Bu}$ çalışmanın temel hareket noktası, Osmanlı sarayında yetişip Karamanoğullarına gelin giden bir sultanın hayatından yola çıkarak bazı bilinmezlikleri tartışmaktır. Bir aile kurmak anlamına gelen evlilik, hanedanlar arasında olduğunda başka amaçlar da gözetilebilmekteydi. Osmanlı'nın kuruluş dönemi evlilikleri şöyle değerlendirilebilir:

“14. ve 15. yüzyıl başlarında Osmanlı hükümdarları ve oğullarının evlilikleri, komşu hanedanların yani Rumeli’nin Hıristiyan ve Anadolu'nun Müslüman güçlerinin prensesleri ve sultanlarıla yapılırdı. Hanedanlar arası evlilikler taktik amaçlıydı; cıva gibi kaygan saflaşmalar ortamında, devletin askeri ve diplomatik konumunu güçlendirmeye elverişli ittifakları

1 Bu kişilerle ilgili bkz. İsmail Hakkı Uzunçarşılı, "Mehmed I", İA, C. VII, MEB Yayınları, Eskişehir 1997; Necdet Sakaoğlu, Bu Mülkün Sultanlan 36 Osmanl Padişahı, Oğlak Yayıncılık, İstanbul 1999; M. Çağatay Uluçay, Padişahlarn Kadinlarn ve Kizlan, Ötüken Yayınları, İstanbul 2012; İbrahim Hakkı Konyalı, Âbideleri ve Kitabeleri İle Konya Tarihi, Burak Matbaası, Ankara 1997; İsmail Hakkı Uzunçarşlı, "Karamanoğulları Devri Vesikalarından İbrahim Beyin Karaman İmareti Vakfiyesi”, Belleten, C.I, S. 1, II. Baskı, TTK Yayınları, Ankara 1995. 
sürdürmek. Osmanlı evliliklerinin çoğu, ya bir saldırı ittifakı görüşmelerinin bir parçası olarak ya da daha sık görüldüğü şekliyle yenilen tarafin boyun eğişi ve vasallık statüsünü kabul edişinin simgesi olarak düzenleniyordu. Osmanlılar evlilik ittifaklarını, iktidar için yarıştıkları yerel Rumeli-Anadolu devletleriyle sınırlamışlardı; bunlar, bir sonraki dönemeçte müttefik de olabilecek, potansiyel düşmanlardı."

Evlilikler, siyasete şekil vermekteydi. Nitekim I. Murad'ın kızı Nefise Hatun'un 1378'de Karamanoğlu Alaeddin ile evlenmesi iki rakip güç arasındaki mücadeleyi uzun süre durdurmuştur ${ }^{3}$. Sonuç olarak ilk dönemlerde siyasi beklentiler ya da kaygılar nedeniyle beylikler ve Osmanlı arasında diplomatik evlilikler olmuştur. Konunun öznesi İlaldı Hatun'un babası Çelebi Mehmed'in çocuklarına değinmek, mevcut bazı sorunları göstereceğinden aşağıda değinilmiştir.

\section{1. Çelebi Mehmed'in Kızları}

Kaynaklarda Çelebi Mehmed'in çocuklarının sayısı ve isimleri hakkında bir birliktelik yoktur. Benzer şekilde onların evlendiği kişiler de farklı ifade edilmiştir. Aşıkpaşazade’ye göre Çelebi Mehmed öldüğünde dört oğlu ve yedi kızı kalmıştır . Sakaoğlu ise Çelebi Mehmed'in sayıları 18 olan oğullarından Mehmed Çelebi, Ahmed Çelebi, II. Murad, Kasım Çelebi, Mustafa Çelebi, Mahmud Çelebi, Yusuf Çelebi ve Orhan Çelebi'nin; dokuz kızından da Ayşe, Hatice, Sultan, Selçuk, İncu ve Hafsa hatunların adlarının bilindiğini söyler ${ }^{5}$. İki görüşün aksine Uzunçarşılı; Sultan Mehmed'in (Çelebi) en büyüğü Murad olmak üzere Mustafa, Kasım, Ahmed, Yusuf ve Mahmud adlarında altı oğlu olduğunu belirtir. Ona göre yedi kızından Selçuk, Hafsa, Sultan, Ayşe ve Hadice hatunların adları bilinmekte ise

2 Leslie P. Peirce, Harem-i Hümayun Osmanh İmparatorluğu’nda Hükümranlık ve Kadınlar, (Çev. Ayşe Berktay), Tarih Vakfi Yurt Yayınları, İstanbul 1996, s. 35.

3 Anthony Dolphin Alderson, Bütün Yönleriyle Osmanlı Hanedanı, (Tercüme eden: Şefaettin Severcan), İz Yayıncılık (Yeni Şafak), Tarihsiz, s. 141.

4 Aşıkpaşazade, Aşıkpaşaoğlu Tarihi, (Hazırlayan: Atsız), MEB Yayınları, İstanbul 1970, s. 100. Çelebi Mehmed'in eşlerinden Dulkadiroğlu Süli Bey'in kızı Emine Hatun, olasılıkla II. Murad'ın annesidir. Adları bilinen diğer iki eşi ise Şehzade Hatun ve Kumru Hatun'du. Sakaoğlu, 36 Osmanlı Padişahı, s. 79.

5 Necdet Sakaoğlu, "Mehmed I (Çelebi)", Yaşamlan ve Yapttlaryla Osmanlilar Ansiklopedisi, C. II, Yapı Kredi Kültür Sanat Yayıncılı,, İstanbul 2008, s. 82; Sakaoğlu, 36 Osmanh Padişahı, s. 79. Aynı yazar bir diğer eserinde ise Çelebi Mehmed'in kızları; Selçuk Hatun, Hafsa Hatun, Ayşe Hatun, Sultan Hatun, İncu Hatun, Ilaldı Hatun ile ismi bilinmeyen iki kızı daha vardı, demiştir. Necdet Sakaoğlu, Bu Mülkün Kadın Sultanlan Vâlide Sultanlar, Hâtunlar, Hasekiler, Kadınefendiler, Sultanefendiler, Oğlak Yayıncılık, İstanbul 2008, ss*. 78-88. 
de diğer iki kızının adları şimdilik meçhuldür ${ }^{6}$. Çelebi Mehmed'in yedi kızı olduğu fikrini Uluçay da benimsemiştir. Bunlardan isimleri bilinenler Selçuk Hatun, Hafsa Hatun, Ayşe Hatun, Sultan Hatun ve İlaldı Hatun'dur . Öztuna ise; I. Mehmed'in ismi bilinmeyen iki kızı ile birlikte Selçuk Hatun, Sultan Hatun, Hatice Hatun, Fatma Hatun, Hafsa Hatun, İlaldı Sultan, Şahzade Hatun ve Ayşe Sultan adlarında 10 kızının adını verir ${ }^{8}$.

İsmi bilinen kızlarının evlilikleri konusunda şu bilgilere ulaşılabilmektedir. Bunlardan Selçuk Hatun (1407-1485), Candaroğullarından İsfendiyar Bey'in oğullarından İbrahim Bey'le 1425 yılında evlenmiştir ve Bursa'da vefat etmiştir ${ }^{9}$.

Vezir-i azam Çandarlızade İbrahim Paşa'nın oğlu Mahmud Paşa ile evlenen Hafsa Hatun, 1443'ten sonra hacca giderek, Mekke'de vefat etmiştir ${ }^{10}$. Neşri'ye göre Sultan Murad'ın kız kardeşiyle evli olan Mahmud Çelebi, Halil Paşa’nın kardeşidir ${ }^{11}$. Uluçay'a göre ise evlendiği kişi Çandarlızade vezir-i azam Halil Paşa'nın oğlu ümeradan Mahmud Çelebi'dir ${ }^{12}$. Ancak Mahmud Paşa, II. Murad'ın vezir-i azamı Büyük İbrahim Paşa bin Hayreddin Paşa'nın oğlu ve vezir-i azam Halil Paşa’nın küçük kardeşidir ${ }^{13}$.

Sultan Hatun (Ö. 1444), 1425 yılında, İsfendiyar Bey’in oğlu Çankırı sancakbeyi Kasım Bey'le evlenmiştir ${ }^{14}$. Diğer kızları ise II. Murad zamanında, Kara-

6 Uzunçarşıll, "Mehmed I", s. 506; İ. Hakkı Uzunçarşll, "Çelebi Sultan Mehmed'in Kızı Selçuk Hatun Kiminle Evlendi”, Belleten, C. XXI, S. 82, 1957, s. 253.

7 Uluçay, a.g.e., ss. 28-30.

8 Yılmaz Öztuna, Devletler ve Hânedanlar Türkiye (1074-1990), C. II, Kültür Bakanlığı Yayınları, Ankara 1996, ss. 124-126.

9 Uzunçarşıll, "Mehmed I", s. 506; Uluçay, a.g.e., s. 28, Sakaoğlu, 36 Osmanlı Padişahı, s. 79. Selçuk Hatun, Sitti Hatun, Hafsa Sultan, Ayşe Sultan ile Çelebi Mehmed'in oğulları 1429'da ölen Mahmud Çelebi ile aynı yıl vebadan ölen Yusuf Çelebi ve 1423'te idam edilen Mustafa Çelebi, Yeşil Türbe'ye defnedilmiştir. Ekrem Hakkı Ayverdi, Osmanh Mímârîsinde Çelebi ve II. Sultan Murad Devri 806-855 (1403-1451) II, Baha Matbaası, İstanbul 1972, s. 116-117.

10 Uzunçarşıll, "Mehmed I", s. 506; Sakaoğlu, 36 Osmanl Padişahı, s. 79. İzladi Muharebesi'nde esir düşen Çandarı ıahmud Çelebi, Sultan Murad'ın kız kardeşinin kocasıydı. Fidyeye karşılığında serbest bırakıldı. Halil İnalcık, Fatih Devri Üzerinde Tetkikler ve Vesikalar I, TTK Yayınları, Ankara 1987, s. 11, 21.

11 Mehmed Neşri, Kitâb-ı Cihan-nümâ, C. II, (Yayınlayanlar: Faik Reşit Unat-Mehmed A. Köymen), TTK Yayınları, Ankara 1987, s. 647.

12 Uluçay, a.g.e., s. 29.

13 İsmail Hakkı Uzunçarşılı, Çandarlı Vezir Ailesi, TTK Yayınları, Ankara 1988, s. 97.

14 Mehmed Süreyya, Sicill-i Osman̂̂, C. 1, (Hazırlayanlar: Nuri Akbayar, Seyit Ali Kahraman), Tarih Vakfi Yurt Yayınları, İstanbul 1996, s. 22; Uzunçarşıll, "Mehmed I”, s. 506; Uluçay, a.g.e., s. 30, 
manoğullarından İbrahim, İsa ve Ali Beyler ile evlenmişler ve birisi de Varna Savaşı'nda şehit düşen Karaca Bey'e verilmiştir ${ }^{15}$. Nitekim II. Murad, 1425 yllında Candaroğlu İbrahim Bey’in kızı Hatice Halime Sultan ile evlendiği zaman üç kız kardeşinin de düğünlerini yapmıştır ${ }^{16}$.

İncu Hatun, Karamanoğlu Alaeddin Bey'in Nefise Hatun'la evliliğinden olan oğlu II. Mehmed'le evlidir ${ }^{17}$. Bu nedenle bazı araştırmacılar İbrahim Bey'in annesi olarak İncu Hatun ismini vermişlerdir. Nitekim Konyal, Vakf-1 İncu Hatun valide-i İbrahim Bey ibni Karaman ifadesinden hareket ederek İbrahim Bey'in annesi ya da analığının İncu Hatun olduğunu söylemiştir ${ }^{18}$. Öztuna ise II. Mehmed Bey'in zevcesi İncu Hatun, Ermenek'teki türbesinde medfundur ki, II. İbrahim'in annesidir, demiştir ${ }^{19}$. Ancak Çelebi Mehmed 1402'de evlendiğine göre İncu Hatun, İbrahim Bey'in annesi olamaz ancak analığı olabilir²

Ayşe Hatun’un doğum ve ölüm tarihi ile kocası ve çocukları hakkındaki bilgiler tartışmalıdır. Edirne'de Ayşe Kadın Camisi’ni yaptırmıştır. Üsküp’te de bir camisi vardır. Alderson'un adını vermediği bu hatunun 1425 'te Karamanoğullarından

Sakaoğlu, 36 Osmanl Padişahı, s. 79. Kasım Paşa, Sultan'ın vefatı üzerine II. Murad'ın kızıyla evlenmiştir. Mehmed Süreyya, Sicill-i Osmanî, G. 3, s. 874.

15 Uzunçarşıll, "Mehmed I", s. 506. Karaca Paşa'nın Selçuk Hatun'la evli olduğu bilgisini verenler de vardır. Mehmed Süreyya, Sicill-i Osmanî, s. 38, 870; Franz Babinger, Fatih Sultan Mehmed ve Zamanı, (Çev. Dost Körpe), Oğlak Yayınları, İstanbul 2003, s. 53.

16 Uluçay, a.g.e., s. 28.

17 Alderson, a.g.e., s. 302.

18 İbrahim Hakkı Konyalı, Âbideleri ve Kitâbeleri İle Karaman Tarihi Ermenek ve Mut Âbideleri, Baha Matbaası, İstanbul 1967, s. 131.

19 Öztuna, a.g.e., s. 64.

20 II. Murad 1404 Haziran'inda dünyaya geldi. Halil İnalcık, "Murad II", IA, G. VIII, MEB Yayınları, Eskişehir 1997, s. 598. Bununla birlikte İncu Hatun ile Karamanoğlu Mehmed Bey'in evliliği 1423 yılından önceydi. Zira Mehmed Bey bahsi geçen tarihte vefat etmişti. 
II. Mehmed Bey’in oğlu İsa Bey'le ${ }^{21}$ evlendiği ileri sürülmüştür² ${ }^{22}$ Öztuna ise Ayşe Sultan'ın (1414?-1469'dan sonra) 1426 yllında Sofya sancakbeyi Karamanoğlu Alaeddin Ali Bey bin Mehmed Bey II ile evlendiğini söylemiştir. Ayşe Hatun'un evli olduğu kişi konusunda farklı fikirler olmasına rağmen vakıflarından yola çıkılarak Karamanoğlu Ali Bey ile evlendiği söylenebilir. Bir diğer kızı Hadice Hatun ise Karaca Paşa ile evlidir ${ }^{23}$.

Yukarıdaki bilgiler özetlenirse; Selçuk Hatun'un İsfendiyar oğlu İbrahim Bey’le, Hafsa Hatun'un Mahmud Paşa'yla, Sultan Hatun'un Kasım Bey'le, Illaldı Hatun'un Karamanoğlu İbrahim Bey'le, İncu Hatun'un Karamanoğlu Mehmed Bey'le, Ayşe Hatun'un Karamanoğlu Alaeddin Ali Bey'le ve Hatice Hatun'un Karaca Bey'le evli olduğu anlaşılmaktadır. Çelebi Mehmed'in bir kızının ise Karamanoğlu Mehmed Bey'in oğlu İsa Bey ile evli olduğu düşünülürse ismi bilinmeyen bir kızı kalmaktadır. Bu evliliklerden hareketle Çelebi Mehmed'in sekiz kızının varlığı söylenebilmektedir. Ancak bu konuda kesin bir neticeye varmanın zorluğu da unutulmamalıdır.

\section{2. İlaldı Sultan'ın Hayatı ve Eserleri}

İlaldı Sultan’ı 1412 yılında doğduğunu belirten Öztuna, Bursa'da hayrat ve evkafi ile Konya'da darulhuffaz vakfi olduğunu, Karamanoğlu II. İbrahim Bey ile 1426 yılında evlendiğini ve 1471 yılında vefat ettiğini ileri sürer ${ }^{24}$. Alderson’un adını vermeden Karamanoğlu Mehmed Bey'in İncu Hatun'dan önceki eşinden olan oğlu

21 Sakaoğlu başka çalışmalarında ise, Edirne'de bir cami yaptıran ve bir mahalleye adını veren Ayşe Hatun'un Karamanoğlu İbrahim Bey'le evlendiğini söylemiştir. Yine Ayşe Hatun'un II. Murad'ın komutanlarından Karaca Bey'le evlendirildiğini öne sürmüştür. Sakaoğlu, "Mehmed I (Çelebi)", s. 82; Sakaoğlu, 36 Osmanl Padişahı, s. 79, 86. Ancak İbrahim Bey’in İlaldı Hatun ile evlendiği bu çalışmada ortaya konulmuştur. Sultan Murad, aradaki akrabalığı yeni karabetle kuvvetlendirmek istediğinden İbrahim Bey'le kardeşleri Ali ve İsa Beylere birer kız kardeşini verdi, İbrahim Bey'e de kuvvet vererek karşılığında Ankara Savaşı sonrası Karamanlılara verilen Hamidili, Beyşehir ve Otlukhisarı'nı vermek şartıyla yardım etti. Konya üzerine giden İbrahim Bey, amcası kaçınca 1423 yılında Karaman beyi oldu. İsmail Hakkı Uzunçarşılı, Osmanlı Tarihi, C. I, TTK Yayınları, Ankara 2011, s. 403.

Uluçay, a.g.e., s. 30; Sakaoğlu, Bu Mülkün Kadın Sultanlan, s. 88.

Öztuna, a.g.e., ss. 125-126; M. Tayyib Gökbilgin, XV. ve XVI. Astrlarda Edirne ve Paşa Livası, VakıflarMülkler-Mukataalar, İşaret Yayınları, İstanbul 2007, s. 321. Zikredilmeyen kızları ve evlilikleri için bkz. Öztuna, a.g.e., ss. 391-392.

Öztuna, a.g.e., s. 125. Bursa'daki vakıflar başka birine ait olmalıdır. Nitekim Bursa'da Halil Paşa'nın kızı İlaldı Hatun 1500 tarihli vakfiyesinde, hanesini çocukların ve yetimlerin okumaları için vakfetmişti. Yine eşi Bali Bey’in ruhu için Hacı Ramazan Camisi’nde tesbih çekilip cüz okunması için vakıf yapmıştır. Uzunçarşılı, Çandarlı Vezir Ailesi, s. 96. 1471 yılı olayları anlatılırken Uzun Hasan'dan yardım talep etmeye giden Illaldı Hatun'un yolda öldüğü belirtilmiştir. Ebu Bekr-i Tihranî, Kitab-ı Diyarbekriyye, (Çev. Mürsel Öztürk), TTK Yay., Ankara 2014, s. 361. 
İbrahim Bey'le evli gösterdiği bir Osmanlı sultanı vardır. Bu, İlaldı Hatun'du ki İncu Hatun ile kardeştir. İbrahim Bey, İlaldı Hatun evliliği ise $1427^{\prime} \mathrm{de}^{25}$ yapılmıştır.

Konyalı'ya göre, Çelebi Sultan Mehmed'in kızı İlaldı Hatun, Osmanlı prensesi Nefise Sultan'dan doğan Karamanoğullarından biriyle evlenmiş ve bu darulhuffazı yaptırmışıı ${ }^{26}$. Ancak Nefise Hatun, Alaeddin Bey'in eşidir. Uzluk ise, 1476 yılı vakıf kayıtlarına düş̧ügü açıklamada "Karamanoğlu İbrahim Bey'e verilen Osmanh prensesi olacak." ${ }^{\prime 27}$ diyerek doğru bir tespitte bulunmuştur. II. Murad'ın kız kardeşi ve İbrahim Bey'in eşi olarak Sultan Hatun ismini zikredenler de vardır ${ }^{28}$. Osmanlı padişahlarının kızlarına ilk zamanlarda Selçuklu geleneğindeki gibi hatun denilmekteydi. Fatih'ten itibaren sultan, ismi bilinmeyenlere ise, devlet hatun ve sultan hatun gibi tabirler kullanılmaktaydı ${ }^{29}$. Ancak kroniklerde ya da daha sonra yapılan çalışmalarda kullanılan sultan hatun isminin bu anlamda mı yoksa Çelebi Mehmed'in kızı Sultan Hatun için mi kullanıldığı tam anlaşılmamaktadır.

Osmanlı padişahları, Bizans ve Sırp kralları ile Anadolu beylerinin kızlarıyla evlenmişlerdi. Bu hissi bir düşünceden ziyade siyasi amaçlıydı. Benzer şekilde Osmanlı hanedanına mensup kadınlar da Anadolu beyleriyle evlendirilirdi. Siyasi olan bu evlilikler müttefik olmak ya da bir anlaşmazlığı çözmek gibi nedenlerle yapılır$\mathrm{d}^{30}$. Karamanoğlu İbrahim Bey'le evlenen İlaldı Sultan'ı da bu anlamda düşünmek gerekir. Zira Osmanlı-Karamanlı mücadelesinin en yüksek seviyede olduğu bir dönemde evliliğin yapılması, bu görüşü desteklemektedir. Ayrıca iki taraf arasındaki

25 Alderson, a.ge., s. 236; Şeyh Ali Semerkandi'nin Karaman'a geldiği sırada 1428-1429'da Karamanoğlu İbrahim Bey ile Osmanlı sultanı II. Murad devri olup, Murad Bey kız kardeşini Sultan İbrahim'le evlendirerek akrabalık ve barış tesis etmiştir. İsmail Hakkı Mercan, "Şeyh Alâeddin Ali es-Semerkandî ve Menâkıb-nâmesi, Menâkıb-nâmeye Göre Osmanlı Karamanlı Mücâdelesi”, XIII. Türk Tarih Kongresi Bildirileri (4-8 Ekim 1999), C. III/1, Ankara 2002, s. 72. Karamanoğlu İbrahim Bey'in eşinin II. Murad'ın kızı olduğunu söyleyenler de vardır. Mehmed Süreyya, Sicill-i Osmanî, C. 3, s. 871.

26 Konyal, Konya Tarihi, s. 950.

27 F. Nafiz Uzluk, Fatih Devrinde Karaman Eyâleti Vakıflan Fihristi, Vakıflar Umum Müdürlüğü Neşriyatı, Ankara 1958, s. 19.

28 Nicolae Jorga, Osmanh İmparatorluğu Tarihi 1 (1300-1451), (Çev. Nilüfer Epçeli), Yeditepe Yayınları, İstanbul 2009 s. 342. İbrahim Bey, Osmanlı padişahı Çelebi Mehmed'in kızı Sultan Hatun ile evlenmiş ve bu evlilikten Kasım, Pir Ahmed, Alaeddin, Karaman, Nure Sofu ve Süleyman adlı altı çocuğu olmuştur. İbrahim Bey'in büyük oğlu İshak ise cariyeden doğmuştur şeklinde biliniyordu. Bilal Gök, "İbrahim Bey Devri (1423-1464) Karaman-Osmanlı Münasebetleri”, Hikmet Yurdu, C. 5, S. 10, 2012, s. 110.

29 Ahmed Akgündüz, Tüm Yönleriyle Osmanl’da Harem, Timaş Yayınları, İstanbul 2012, s. 178.

30 Yapılan bu tür evlilikler hakkında bkz. Öztuna, a.g.e., s. 108-137, 390-392; Peirce, a.g.e., ss. 35-36, $52-55$. 
mücadelelerden sonra barış görüşmelerine İlaldı Sultan’ın aracı olarak gönderilmesi de anlamlıdır. Bunun yanında kocası ile kardeşi arasında kalan sultanın ruh halinin çok iyi olmadığı da söylenebilir.

\section{a. İbrahim Bey ve İlaldı Sultan'ın Çocukları}

I. Murad'ın kızının torunu olan ve 1406 yılında doğduğu düşünülen II. İbrahim Bey, 58 yıl yaşamış ve yaklaşık 40 yıl tahtta kalmıştır ${ }^{31}$. Karamanoğlu Mehmed Bey’in oğlu olan İbrahim Bey'in annesinin adı İncu Hatun'dur ve Mut'taki türbesinde gömülüdür ${ }^{32}$ diyen Konyalı'nın tespiti doğru değildir. Zira İncu Hatun onun analığıdır. Çelebi Mehmed'in en büyük çocuğu olan II. Murad 1404'te doğduğuna göre İncu ondan sonra doğmuştur. Benzer şekilde İbrahim Bey’in doğum tarihine bakılarak İncu ile yaklaşık olarak aynı yaşlarda olduklarını söylemek mümkündür. Bu bakımdan Karamanoğlu Mehmed Bey'le evlenen İncu'nun İbrahim Bey'in analığı olduğu ortaya çıkmaktadır. Yine 1432 yılında Karaman ülkesine uğrayan Bertrandon'un, "Hükümdar otuz iki yaşlarnda yakışıh bir prensti ve ülkesinde çok sayılan bir insandı. Bana söylendiğine göre annesi Hristiyanmış ve doğduktan sonra kokusunu almak için Rum usullerine göre vaftiz edilmiş." 33 demesi İbrahim Bey'in annesinin cariye olabileceğini akla getirmektedir. Yine İbrahim Bey'in 30'lu yaşlarda olduğu da anlaşılmaktadır. İncu ile ilgili bu yaklaşımların yanı sıra İbrahim Bey ile İlaldı Hatun’un çocukları hakkında da farklı görüşler mevcuttur.

Neşri, İbrahim Bey vefat edince İshak, Pir Ahmed, Karaman, Kasım, Alaeddin, Süleyman ve Nure Sofi adlarında yedi oğlunun kaldığını belirtir. Süleyman ile Nure Sofi'nin kaçıp Sultan Mehmed'e geldiklerini, diğerlerinin ise Karaman’da olduklarını söyler. Bunların yanında çocuklarının büyüğü olan İshak’ın bir cariyeden doğduğunu, diğgerlerinin ise Çelebi Mehmed'in kızı Sultan Hatun'un çocukları olduğunu ekler ${ }^{34}$. İbn Kemal de Alaeddin yerine Ali ismini vererek yedi oğlunu saymışır. Annelerini Yıldırım Han kızı Sultan Hatun ${ }^{35}$ olarak ifade et-

Öztuna, a.g.e., s. 64.

Konyal, Konya Tarihi, s. 950. Uzunçarşılı da benzer şekilde İbrahim Bey'in babası Mehmed Bey, annesi İncu Hatun'dur, demiştir. Uzunçarşılı, "Karaman İmareti Vakfiyesi”, s. 111.

Bertrandon De La Broquiére'in Denizaşın Seyahati, (Editör: Ch. Schefer), (Çeviren: İlhan Arda), Eren Yayınları, İstanbul 2000, s. 188.

4 Mehmed Neşri, a.g.e., s. 771. Halil Edhem de yedi oğlu olduğunu kabul ederek Neşri'deki isimleri vermiştir. Halil Edhem, "Karaman Oğulları Hakkında Vesâik-i Mahkûka", TOEM, S. 13, İstanbul 1330, s. 833.

İbn Kemal, Tevârih-i Âl-i Osman, VII. Defter, (Hazırlayan: Şerafettin Turan), TTK Yayınları, Ankara 1991, s. 237. Şikari de benzer şekilde Bayezid Han'ın kızı vardı, Ibrahim Han’a verdiler, demiştir. Şikârî, Karamannâme [ Zamann Kahraman Karamanîlerin Tarihi ], (Hazırlayanlar: Metin 
miştir. Ancak çocukların annesinin adı İlaldı Hatun olmakla birlikte Çelebi Mehmed'in kızıdır. Dolayısıyla her ikisi de Sultan Hatun ismini kullanmışlardır. Bunun yanında vakfiyede adı geçen Mehmed adlı oğlunu yazmamışlardır ${ }^{36}$. Şikari'ye göre ise, Osmanoğlu kızından yedi oğlu olan İbrahim Bey'in büyük oğlu Kasım Bey'dir. İshak, Alaüddin, Halil, Pir Ahmed, Yakub ve Küçük Mustafa diğer oğullarıdır. Şikari, İbrahim Bey'in hastalığı esnasında oğullarını başına toplayıp Kasım Bey'i yerine tayin ettiğini, İshak'a ve diğerlerine de yerler verdiğini belirtir ${ }^{37}$. Ancak Şikari; Karaman, Süleyman ve Nure Sofi'den bahsetmemiştir. Büyük oğlu İshak olmasına rağmen Kasım adını zikreden Şikari, İlaldı Hatun'un ismini ise zikretmez. Bunların dışında Bekai altı, İbn Tagri-birdi ise altı veya yedi oğlundan bahsetmektedir ${ }^{38}$.

İbrahim Bey'in çocuklarından ikisi hariç (Mehmed Bey ve İshak Bey) hepsinin annesi, Çelebi Mehmed'in kızıdır ${ }^{39}$. İbrahim Bey'in en büyüğü Mehmed, sonra İshak ve sirasıyla Pir Ahmed, Kasım, Karaman, Alaüddin, Süleyman ve Nure Sofi adlarında sekiz oğlu vardı. Babasının sağlığında vefat eden Mehmed Bey'den

Sözen, Necdet Sakaoğlu), Karaman Valiliği-Karaman Belediyesi Yayını, İstanbul 2005, s. 233.

36 Nitekim İbrahim Bey'in İmareti Vakfiyesi’nde kendi tuğrasının yanında oğullarından İshak, Mehmed, Pir Ahmed ve Kasım'ın tuğraları görülmektedir. Uzunçarşıll, "Karaman İmareti Vakfiyesi", s. 57. Bunun yanında Halil Edhem, 1471-1472 tarihli Edirne Darulhadis Medresesi bahçesinde bulunan mezardan hareketle Karaman'ın Karamanoğlu II. Mehmed Bey'in oğlu olduğunu ifade ederken Öztuna ise 1471'de Edirne'de ölen Alaüddin Karaman Bey Osmanlı hizmetine girmiştir. Çirmen sancakbeyi iken şehit oldu. Edirne'de darulhadisteki türbesinde medfundur, demiştir. Halil Edhem, "Karaman Oğulları Hakkında Vesâik-i Mahkûka", TOEM, S. 14, İstanbul 1330, s. 877; Öztuna, a.g.e., s. 64.

37 Şikari, a.g.e., s. 234. 1500 tarihli Karamanoğulları silsilenamesinde sırasiyla Nure Sufi, Karaman Bey, Mahmud Bey, Halil Bey, Alaeddin Bey, Mehmed Bey, İbrahim Bey ve Kasım Bey isimleri verilmiştir. Kasım evladından bir kimsenin iki oğluyla Mısır'da olduğu belirtilmiştir. Alaeddin Bey'den Kasım Bey'e kadar olan bu sıralamanın beylik ettiği de vurgulanmıștır. Topkapı sarayı Müzesi Arşivi Belgeleri (TSMA.E), 748/52. 1483 yllında Kasım Bey'in ölümünden sonra Turgutoğlu başlarında olmak üzere Larende halkının isyan ettiği Karagöz Mehmed Paşa tarafından bildirilmiştir. Taşili halkının bazısı itaat ederken bazısı Turgutoğlu'na katılmıştı. Taşili Kemal Paşa'ya verilmiş ama o bile gelmemişti. Bu belgeden 1485 yllında Osmanlı'nın hala bölgede timar düzenini tam kuramadığı anlaşılmaktadır. Zira yirmi bin ve otuz bin akçe timar tasarruf eden kimselerin ne cebesi ne de merd nökeri vardı, hemen birer atlı kalanıyla gelmişlerdi. Karaman askerinin durumu da böyleydi. TSMA.E, 754/63. Bu, Osmanlı teşkilatının bahsedilen yıllarda Karaman'da tam kurulamadığını göstermektedir.

38 M. C. Şehabeddin Tekindağ, "Son Osmanlı-Karaman Münasebetleri Hakkında Araştırmalar", Tarih Dergisi, C. XIII, S. 17-18, İstanbul 1963, s. 49.

39 Öztuna, a.g.e., s. 65. 
sonra en büyük oğul olarak kalan İshak Bey’in validesi de sultan değildi ${ }^{40}$. Bertrandon'un "Benim buraya gelişimden altn gün önce karlarndan birini öldürtmüs, işe bakın ki bu kadın büyük oğlunun annesiymiş ve oğlun bu olaydan hiç haberi yokmuş; nitekim ben kendisini gördüğ̈̈mde bu konuda henüz bir şey bilmiyordu. Ve o, Büyük Türk Beyi Murad'ın kız kardesiyle evliydi. " ${ }^{41}$ bilgilerini vermesi hem onun iki eşi olduğunu desteklemekte hem de büyük çocuklarının annesinin farklı olduğunu ortaya koymaktadır. Ayrıca 1432 yılından önce İbrahim Bey ile İlaldı Hatun’un evlendiğini de teyit etmektedir.

Karaman hükümdarı İbrahim'in en büyük oğlunun annesi cariyeydi ama diğer oğullarının birçoğu Osmanlı sultanı I. Mehmed'in kızı İlaldı Hatun'un çocuklarıyd1 ${ }^{42}$. İbrahim Bey, "Íshak Beyden gayrisinde Osmanlılk alacası vardır diye sevmezdi." diyen Neşri, gelişen olayları şöyle anlatmıştır: Hasta olunca Sultan Hatun'dan olan oğulları ittifak ederek Konya'yı muhasara ettiler. İbrahim Bey’i kaçırıp, Gevele’ye çıkarmak istediler. İçeri girmeden kapıda öldü. Bu oğlanlar anlaşıp İshak'ı sürdüler, Pir Ahmed'e büyük kardeş olduğu için biat ettiler ${ }^{43}$. İbn Kemal de benzer şekilde “... Bâkisinde irk-ı 'Osmanî olub, İshak cariyeden olmağın babasinun aña meyli vardı. Çïn bu Sultan Hatun'dan olanlar, ataları, İshak'ı beklediğin işitdiler ..." ${ }_{44}$ demiştir.

Alderson'un oluşturduğu tabloya göre; Çelebi Mehmed'in kızı İncu ile Karamanoğlu Mehmed Bey evlenmiştir. Mehmed Bey'in oğulları İbrahim, Ali ve İsa da Çelebi Mehmed'in kızlarıyla evlenmiştir. Tabloda bu kızların isimleri belli değildir. İbrahim Bey'in 1427'de evlendiği gösterilirken diğgerlerinin evlilik tarihi 1425 olarak yazılmıştır. Aynı tabloda İbrahim Bey'in bu evlilikten olan çocukları Alaeddin (Ö. 1466), Karaman, Kasım (Ö. 1483), Mehmed (Ö. 1463), Nure Sufi, Pir Ahmed (Ö. 1474), Süleyman ve bir kızı gösterilmiştir ${ }^{45}$. Ancak İbrahim Bey ile

İsmail Hakkı Uzunçarşıll, Anadolu Beylikleri ve Akkoyunlu, Karakoyunlu Devletleri, TTK Yayınları, Ankara 2011, s. 30; Uzunçarşıll, "Karaman İmareti Vakfiyesi”, s. 125; Tahsin Ünal, Karamanoğullar Tarihi, Berikan Yayınları, Ankara 2007, s. 417, 61 1; M. C. Şihâbeddin Tekindă̆, "Karamanlılar", İA, C. VI, MEB Yayınları, Eskiş̧ehir 1997, s. 326.

Bertrandon, a.g.e., s. 188.

Peirce, a.ge.e, s. 54. Aynı yazar, İbrahim'in yedi oğlundan İshak cariyeden diğerleri Osmanlı sultanı I. Bayezid'in kızı Sultan Hatun'la evliliğinden olmaydı, demiştir. Peirce, a.g.e., s. 59. Her iki bilgi de Kemalpaşazade'ye dayandııılmakla birlikte hem kızın adı hem de babasının adı farklı verilmiştir. Yazarın çok emin olmadan verdiği bilgilerden dipnotta verilen bilginin yanlışlığı yukarıda değerlendirilmiştir. 
İlaldı Sultan'ın evliliğinden Pir Ahmed Bey, Karaman Bey, Kasım Bey, Alaeddin Bey, Süleyman Bey, Nure Sufi Bey adlı oğulları ile Fatih Sultan Mehmed'in eşi olan kızları olmuştur ${ }^{46}$.

\section{b. İlaldı Sultan Darulhuffazı}

İlaldı Hatun, Karamanoğlu İbrahim Bey'le evlenerek Osmanlı sarayından Karaman sarayına gelin geldikten sonra Konya'da bir darulhuffaz yaptırmışır. Darulhuffazın ne zaman yaptırıldığı bilinmemektedir. Ancak İlaldı Hatun'un yaşadığı dönem ile Sultan İbrahim’le evlendiği zaman göz önüne alınarak yaklaşı bir tarih verilebilir. Bu yaklaşıma göre vakfin 1427-1463 yılları arasında kurulduğu söylenebilir.

Hem Kur'an-1 Kerim'in öğretildiği ve okutulduğu hem de hafizların yetiştirildiği genelde bir türbe içerisinde faaliyet gösteren kurumlara darulhuffaz denilirdi. Bu tür vakıflarda hafizların Kur'an-1 Kerim okuması, yerine getirilmesi gereken en önemli şartlardandı. Vakfiyede belirtilen kurallar çerçevesinde idare edilen darulhuffazın geliri, verilecek ücretleri ve öğrenci sayılarını etkilemekteydi ${ }^{47}$. İlaldı Sultan Darulhuffazı'nda hafizlara ücret de verilmişti. Bu uygulama sayesinde hafizlar ücretsiz okudukları okulda aynı zamanda para kazanmıştı. Yine bu ücret, ailelerine yük olmadan kendi ihtiyaçlarını karşılayabilmelerine de olanak sağlamıştır.

Günümüzde toplumun her kesiminde var olan kadınlar, Osmanlı ve Karamanlı toplumunda geri planda mıydı? Yoksa bilinenin aksine sosyal hayatın içinde

46 Öztuna, a.g.e., s. 126. Öztuna’ya göre kızın adı Gülşah Hatun'dur. Öztuna, a.g.e., s. 136. Karamanoğlu İbrahim Bey’in Karaman'daki imareti içerisindeki türbede İbrahim Bey ile oğullarının mezar taşları vardır. Mezar taşlarında İbrahim Bey'in 1465, Alaeddin Bey'in 1465 ve Kasım Bey’in 1483 yılında öldügü yazılıdır. Konyalı, Karaman Tarihi, s. 512.

47 Cahid Baltacı, XV-XVI. Asırlarda Osmanh Medreseleri, C. I, M.Ü. İlahiyat Fakültesi Vakfi Yayınları, İstanbul 2005, s. 68-69; Mehmet Zeki Pakalın, Osmanl Tarih Deyimleri ve Terimleri Sözlüğ̈̈, C. I, MEB Yayınları, İstanbul 1993, s. 399; Yusuf Küçükdağ, Konya Darülkurralan (1400-1920), Çizgi Kitabevi Yayınları, Konya 2014; ss. 7-9; Nebi Bozkurt, "Dârülkurrâ", DİA, C. VIII, 1993, s. 543. Konya'da kadınlar tarafından kurulan vakıflar arasında İlaldı Sultan'a da değinilmiştir. Doğan Yörük "Selçuklu'dan Osmanlı'ya Konya'da Vakıf Kuran Kadınlar”, Geçmişten Günümüze Şehir ve Kadın I, (Edit. Osman Köse), Samsun 2016, s. 477. Osmanlı Devleti’nin kuruluşundan 1512 yılına kadar geçen süreçteki kadınların yaptırdığı binalar ve bunların şehirlere etkisi hakkında bkz. Ayşe Çıkla Bölükbaşı, "Erken Osmanlı Devletinde Kadınların Mimari Alandaki Hamiliği (12991512)", Sanat Tarihi Fillı̆̆, S. 19, 2007, ss. 73-90. Kadınların kurduğu vakıflar hakkında bkz. Fatih Bayram, Zâviye-Khankâhs and Religious Orders in the Province of Karaman: The Seljukid, Karamanoğlu and the Ottoman Periods, 1200-1512, Bilkent Üniversitesi Yayımlanmamış Doktora Tezi, Ankara 2008. Kadınlara ait vakıf örneği için bkz. Hamit Şafakcı, "Turgutoğulları'ndan Sultan Hatun'un Vakfi", Vakıflar Dergisi, S. 44, Ankara 2015, ss. 49-72. 
miydi? Tek bir örnek üzerinden bu sorulara cevap vermek yetersiz olur. Ancak İlaldı Hatun, varlıklı kadınların gelirini toplum yararına vakfedebildiğini göstermektedir. Aynı zamanda kadınların siyasi hayatta da aktif rol oynayabildiği anlaşılmaktadır. Kadın; aile içinde çocuk, eş, anne ya da hanedan üyesi gibi farklı işlevleriyle hayatın içindedir. Bu anlamda kadın; idarî, ailevî, ticarî ve hayrî işlerin merkezinde olarak toplumsal hayatın içerisindeydi, denilebilir.

\section{Vakfin Gelir ve Giderleri}

İlaldı Hatun'un kurduğu vakfin belirli gelirleri vardı. 1476 yılı verilerine göre darulhuffazın Şadi Bey Hamamı'ndan 12 sehimden yedi sehim ile bu hamamın karşısındaki dükkanlardan elde edilen gelirleri bulunmaktaydı. Dolayısıyla bu hisseden vakfa 10.000 akçe gelir gelmiştir. Bunun yanında hamamın karşısındaki dükkanlardan elde edilen gelir de vakfa yazılmıştır. Ayrıca Larende’de İbrahim Bey'in hatununun cüzleri vakfina Emekseven köyünden de yer kaydedilmiştir ${ }^{48}$. Vakfin en önemli geliri olan Şadi Bey Hamamı, Karamanoğlu ileri gelenlerinden Şadi Bey tarafindan bir darüşşifa ile birlikte yaptırılmıştır ${ }^{49}$. 14 Şubat 1425 tarihli Arapça vakfiyesinde hamamın gelirini misafirhanesine vakfetmiştir ${ }^{50}$. Ancak bu tarihte darulhuffaz ile ilgili bir bilgi vakfiyede yoktur. Çünkü darulhuffaz bu tarihten sonra kurulmuş ve hamamın bir kısım gelirleri de buraya aktarılmıştır. Muhtemelen İbrahim Bey’in emri ile hamamın bir kısım geliri darulhuffaza verilmiştir. Bu fikirden hareketle de vakfin 1463 yılından önce kurulduğu söylenebilir. Ayrıca vakfiye tarihinin 1425, evliliğin 1427 yılında olması, darulhuffazın 1427-1463 aralığında kurulduğunu göstermektedir.

1483 yılında Şadi Bey Hamamı'ndaki hisseden vakfin geliri 7.140 akçeydi. Hamamın karşısındaki yedi dükkândan ise yıllık 120 akçe gelir gelmiştir. Dük-

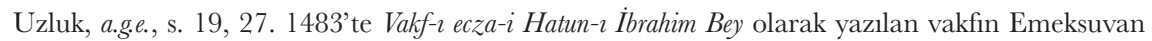
köyündeki iki kıta zeminden yılık 50 akçe geliri vardı. Mehmet Akif Erdoğru, "Murad Çelebi Defteri: 1483 Yılında Karaman Vilâyetinde Vakıflar-II-", Tarih Incelemeleri Dergisi, XVIII, S. 2, 2003, s. 121.

49 Yusuf Oğuzoğlu, “17. Yüzyılda Konya Şehrindeki İdari ve Sosyal Yapılar”, Konya, (Hazırlayan: Feyzi Halıcı), Güven Matbaası, Ankara 1984, s. 103. Oğuzoğlu’nun İnce Minare civarında olduğunu ifade ettiği Şadi Bey Hamamı, Konyalı’ya göre ise Yıkık mahalledeki Şadi Bey Ağa Camisi ile Sahip Ata Darulhadisi arasında idi. Buna Çifte Hamam da derlerdi. Hamamın adı Şazbey ya da Şad Bey gibi de kullanılmıştır. Bkz. Konyalı, Konya Tarihi, ss. 540, 1066. Bu vakfin yeri için bkz. Yusuf Küçükdağ, "Konya'da Alâeddin Dârüş-şifâsı, Tıp Medresesi ve Mescidinin Yeri, Yapısı", Osmanlı Araştırmalan, S. IX, İstanbul 1989, ss. 347-359. 
kanlardan elde edilen gelir kandile konulan yağa yani aydınlatmaya harcanmıştır. Toplam 7.260 akçe geliri olan vakıfta; günlük 10 hafiza 10 akçe, imama bir akçe, müezzine ayda beş akçe ücret verilmiştir ${ }^{51}$. 1500 yılında da aynı gelir ve gidere sahip olan vakfin toplam geliri 7.260 akçeydi $^{52}$.

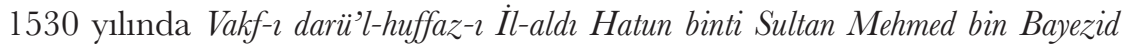
Han der Konya şeklinde yazılan vakfin geliri 7.100 akçeydi. Hamamın karşısındaki iki dükkândan elde edilen 144 akçede eklenince toplam geliri 7.244 akçeye ulaşmıştır ${ }^{53}$. Dükkân sayısı azalmasına rağmen gelirin artması dikkati çekmektedir. Yine 16. yüzyılın ilk yarısına ait bir tahrirde İlaldı Hatun eczası ve mescidi vakfinın gelirleri, hamamdaki hisseden 7.000 akçe ve iki dükkândan 44 akçe olmak üzere 7.044 akçeydi. Dükkândan elde edilen gelir revgan-ı çerağ ${ }^{\breve{5}}$ için harcanmıştır. Yine tevliyet, nezaret, imamet, müezzin ve eczahan cihetlerine toplam 6.940 akçe verilmiştir. Mum yağına 44 akçe ve hasır seccadeye 72 akçe ödenmiştir. Dolayısıyla vakfin toplam masrafi 7.056 akçeydi $^{55}$. Gelir gider dengesine bakılırsa vakfa ait bütün gelirlerin masraflara gittiği hatta gelirin üzerine çıkıldığı anlaşılmaktadır. Bu tarihte vakfin yanında mescit olduğu da ilk defa zikredilmiştir.

1584 yllında darulhuffaz ve mescidin, suyu şehir suyundan karşlanan Şadi Bey Hamamı'ndan yedi hisseye karşılık geliri 7.100 akçeydi. Toplam geliri 13.000 akçe olan hamamın kalan 5.900 akçe hissesi ise Şadi Bey Zaviyesi'nin ${ }^{56}$ vakfiydı. Vakfın, hamamın karşısındaki yedi dükkândan ise yıllık 100 akçe geliri vardı. Tev-

51 Mehmet Akif Erdoğru, "Murad Çelebi Defteri: 1483 Yılında Karaman Vilâyetinde Vakıflar-I-", Tarih İncelemeleri Dergisi, XVIII, S. 1, 2003, s. 156.

52 Tapu Kadastro Genel Müdürlüğü Arşivi (TKGMA) Tapu Tahrir Defterleri (TD): 565, v. 24b-25a.

53387 Numarah Muhâsebe-i Vilâyet-i Karaman ve Rûm Defteri (937/1530) I, Devlet Arşivleri Genel Müdürlüğü, Osmanlı Arşivi Daire Başkanlığı Yayınları, Ankara 1996, s. 32.

54 Çerağ, topraktan veya madenden, içine yağ konulup yan tarafindaki deliğe bir fitil takılarak yakmaya mahsus eski yağ kandillerine verilen addı. Pakalın, a.g.e., s. 351.

55 Seyit Ali Kahraman, XVI. Yüzynl Başlarnnda Karaman Vilâyeti Vakıflar, Kayseri Büyükşehir Belediyesi Kültür Yayınları, Kayseri 2009, s. 89.

56 Şadi Bey'e ait bir mescit ve imaret vardı. 3-12 Nisan 1736 tarihinde, Şadi Bey Mescidi evkafinın nezaretine atanan Seyyid Ahmed Halife ayn zamanda mescidin müezziniydi. Konya Ser iye Sicilleri (KŞS) 53, s. 295-2. 13 Mayıs 1807 tarihinde ise Şadi Bey İmareti’nde günlük bir akçe ile tabbah olan es-Seyyid Ahmed, es-Seyyid Halil ve es-Seyyid Hasan bin es-Seyyid Abdurrahman adlı kardeşlerden ikisinin ölmesi üzerine onların görevleri kardeşleri Ahmed'e verilmiştir. KŞS 69, s. 5-2. Bu atamalar, vakfin misafirhane özelliğini 19. yüzyllda da devam ettirdiğini göstermektedir. 
liyet görevini yapan kişi günlük dört akçe ücret almıştı 10 hafiz ile müezzin ve imam ücretleri, vakfin diğer masrafları arasındayd ${ }^{57}$.

\section{Vakfın Görevlileri}

İlaldı Hatun Darulhuffazı'ndaki işler, çeşitli görevliler tarafindan yerine getirilmiştir. Nitekim 1476 yılında Bayezid Han oğlu Mehmed Han kızı İlaldı Hatun Darulhuffazı Vakfı olarak yazılan vakfin tevliyeti Ahi Ali oğlu tarafindan yürütülmekteydi. 1476 yılında Konya'daki Şadi Bey'e ait zaviye ve mescit vakfının meşihatı ise Mevlâna Ubeyit adına yazılırken tevliyet Ahi Ali oğlu tasarrufundaydı. Vakfiyesinin görüldüğü belirtilen vakfin gelirleri sayılırken zaviye yanındaki Şadi Bey Hamamı'ndan hisse gelirleri arasında yer almıştı. Vakfiyede mütevelli olacak kişi, gelirin altıda biri karşılığında bu görevi yapacaktı ${ }^{58}$. Şadi Bey Vakfi ile İlaldı Hatun Darulhuffazı'ndaki görevliler aynıdır. Yine hamamın gelirleri iki vakıf arasında paylaştırılmışıı ${ }^{59}$. Bazı görevlileri aynı olan İlaldı Hatun ve Şadi Bey vakıflarının aynı vakfiyedeki şartları kullandıkları anlaşılmaktadır. Bu nedenle iki vakıfta görevli olanların ücretlerinin de birlikte ödendiği düşünülmektedir.

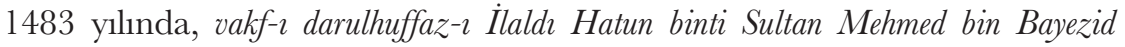
Han der Konya olarak yazılan vakfin tevliyet görevini Mevlâna Nizami’nin oğulları Hüsrev Çelebi ile Cafer Çelebi yapmaktaydı. Tevliyet görevini yürütenlere vakfin gelirinin altıda biri ayrılmıştı. İlaldı Hatun ile Şadi Bey vakıflarının nezaretinin birlikte olması padişahın hükmüyle olmuştu, zira vakfiyede böyle bir hüküm yoktu. 1483 yılında 10 hafiza günlük 10 akçe, imama bir akçe, müezzine ise ayda beş akçe ücret hesap edilmiştí ${ }^{60} 1500$ yılında da bu kişiler aynı şartlarla tevliyet görevine devam etmekteydi. Vakfiyede olmamasına rağmen vakfin nezareti, Şadi Bey Vakfi'yla birlikte yürütülmüştü. Vakıfta ayrıca 10 hafiz, bir imam ve bir müezzin görevliydi. Müezzin ayda 10 akçe ücret almıştı ${ }^{61}$. Bu bilgiler herhangi bir sıkıntı

TKGMA, TD 584, v. 12a. O halde 1584'te yıllık 360x4=1.440 akçe tevliyet görevini yapanlara verilmiştir. Halife'ydi. Mütevelli ise Şadi Bey'in azath kölesi Yusuf bin Abdullah'tı. Şadi Bey Hamamı'ndan vakıf hissesine 5.400 akçe düşmüștü. Hicri 826/1423 tarihli vakfiyede tevliyet ciheti 1/6'ydı. Fahri Coşkun, 888/1483 Tarihli Karaman Eyaleti Vakrf Tahrir Defteri, İstanbul Üniversitesi Sosyal Bilimler Enstitüsü Yayımlanmamış Yüksek Lisans Tezi, İstanbul 1996, s. 46; Erdoğru, "VakıflarII-", s. 99.

60

61

TKGMA, TD 565, v. 24b-25a. 
olmazsa aynı kişilerin ölene kadar vakıftaki görevlerine devam ettiğini ve vakıftaki görevli sayısının da aynı kaldığını göstermektedir. Yine vakfiyede bulunan ya da sonradan oluş̧urulan şartların aynen devam ettirildiği de anlaşılmaktadır.

1518 ve 1522 yillarında yapilan tahrirlerde Konya'nın Şemseddin Mahallesi'nden Lütfi veledi Mehmed mütevelli-i türbe-i İlald Hatun ba-berat ${ }^{62}$ olarak yazılmıştır. Bu kaydın en önemli yanı İlaldı Hatun'a ait Konya'da bir türbe olduğunu kanıtlamasıdır. Buradan hareketle darulhuffaz ile türbenin aynı yerde olduğu ve hafizların Kur'an-ı Kerim okumayı türbede yerine getirdikleri söylenebilir. 16. yüzyılın ilk yarısına ait başka bir tahrire göre de İlaldı Hatun Vakfi'nda cüz okunmaktaydı. İlaldı Hatun tarafından bir de mescit yaptırıldığı anlaşılmaktadır. Mütevelli olanlara ylllık 1.800 akçe verilirken 13 eczahana ise günlük 13 akçeden yıllık 4.680 akçe ücret verilmişti. Nezaret görevi için ise yıllık 180 akçe ayrılmıştı. Benzer şekilde imam olanlara da yıllık 180 akçe ücret tahsis edilmişti. Müezzinin ücreti ise yıllık 100 akçeydi $^{63} .1584$ yılında darulhuffaz ve mescit vakıflarının Sultan Mehmed kızı İlaldı Hatun vakıfları olduğu tekrar edilmiştir. Tevliyete günlük dört akçe yazılırken vakıftaki diğer görevliler 10 hafız, bir imam ve bir müezzindi. Düşülen derkenarda rakabeden sonra artan galle kadar hisseleri taksim edilir denmiştir ${ }^{64}$.

Konya'da Şadi Bey ve İlaldı Hatun Vakfi'nda cüzhan olan Ahmed ölünce görevi Şubat 1697 tarihinde bir akçe ile Abdullah'a verilmiştir ${ }^{65}$. Burada dikkati çeken nokta iki ayrı vakıftaki görevlilerin aynı olmasıdır. Nitekim 4 Mart 1718 tarihinde de iki vakıfta cüzhan olan Mehmed'in beratı yenilenmiştir ${ }^{66} .1739$ yllında hamam, tamamen haraptr ${ }^{67}$. Yani bahsi geçen vakfin en önemli gelir kaynağı kullanılamaz haldeydi. Buradaki verilere göre 15. yüzyılın ilk yarısında kurulan vakfin 18. yüzyılın ilk yarısına kadar faaliyetine devam ettiği anlaşlmaktadır. Ancak daha sonra vakfa dair herhangi bir verinin olmaması vakfin ortadan kalktı̆̆ı izlenimini vermektedir. Muhtemelen geliri azalan vakıf bir başka vakfa katılmış olmalıdır. Yine bir ihtimal gelirinin büyük bölümünü paylaştı̆̆ı Şadi Bey Vakfi’na

Başbakanlık Osmanlı Arşivi (BOA) Tapu Tahrir Defterleri (TT.d) 63, s. 18; BOA, TT.d 455, s. 12.

Kahraman, a.g.e., s. 89.

TKGMA, TD 584, v. 12a.

Vakıflar Genel Müdürlüğü Arşivi Hurufat Defterleri (VGMA, HD) 1140, v. 239b.

VGMA HD 1107, v. 35a. Vakıflar Genel Müdürlüğü Arşivinde yapılan çalışmada, kullanılan hurufat defterleri dışında vakfa dair bir kayda rastlanılmamasına rağmen İlaldı ismiyle Bergama ve Üsküp'te birer vakıf olduğu anlaşılmıştır. VGMA.d 728, s. 248; VGMA.d 460, s. 64.

67 Konyal, Konya Tarihi, s. 540. 
eklenmiş olabilir. Nitekim geliri azalan vakıfların başka vakıflara katılması yönünde bir uygulamanın olduğu bilinmektedir.

\section{Karamanoğlu İbrahim Bey Döneminde Osmanlı ile Mücadeleler ve Bu Mücadelelerde İlaldı Sultan'ın Rolü}

Karamanoğlu Mehmed Bey bir top atışı sonucu ölünce İbrahim, Ali ve İsa adlı oğulları ile amcaları Bengi Ali Bey kaldı. Amcaları Karaman tahtına oturunca üç kardeş Osmanlı hükümdarı II. Murad'a müracaat ederek kendilerine yardım etmesini istediler. Buraya kadar anlatılan hadisede Osmanlı kaynakları genelde ittifak etmektedir ${ }^{68}$. II. Murad'dan aldığı destekle Karaman beyi olan İbrahim Bey, Hamidili'nden aldığı yerleri iade etti. Sultan Murad da buraları Şarabdar İlyas'a verdi. Bu arada II. Murad, üç kız kardeşini Ali, İsa ve İbrahim ile evlendirdi. Ali’ye Sofya sancakbeyliği ve İsa Bey'e Rumeli’nden bir sancak verildi ${ }^{69}$. Bu evlilik sayesinde alınan destekle kardeşlerden biri Karaman beyi olurken diğerleri Osmanlı yönetiminde sancakbeyi olarak görevlendirilmişti. Fakat bu iyi ilişkiler çok uzun sürmedi.

Aşıkpaşazade'ye göre; 839/1435-1436 yılında ${ }^{70}$ Osmanlılar, düşmanlarıyla ittifak eden Karamanoğlu üzerine yürüdüㄲ․ Karaman’ın İçil'den gayrısı itaat et-

68 Karamanoğullarına ait bir tarih yazan Şikari bunun aksini şu sözlerle ifade etmiştir: "Mehmed Bey top atıšyla ölünce Íbrahim Han şah kuldılar. Dört kardes idiler: İshak, Halil, Alaüddin ve İbrahim Han. Hepsinden büyük olduğu için onu şah eylediler. Amcass Ali Bey ile Mahmud Paşa'ya Akşehir'i verdi." Şikari, a.g.e., s. 230.

69 Bu konuda bkz. Aşıkpaşazade, a.g.e., s. 100; Mehmed Neşri, a.g.e., s. 593; İdris-i Bitlisî, Heşt Behişt, C. II, (Hazırlayanlar: Mehmet Karataş, Selim Kaya, Yaşar Baş), Bitlis Eğitim ve Tanıtma Vakfi Yayınları, Ankara tarihsiz., s. 333; Hoca Sadeddin Efendi, Tacü’t-tevarih, C. II, (Hazırlayan: İsmet Parmaksızoğlu), Kültür Bakanlığı Yayınları, Ankara 1979, ss. 156-157; Solak-zâde Mehmed Hemdemî Çelebî, Solak-zâde Tarihi, C. I, (Hazırlayan: Vahid Çabuk), Kültür Bakanlığı Yayınları, Ankara 1989, ss. 214-215; Lütfi Paşa, Tevarih-i Âl-i Osman, (Hazırlayan: Kayhan Atik), Kültür Bakanlığı Yayınları, Ankara 2001, s. 177. Lütfi Paşa; Ali Bey ile İbrahim Bey arasında mücadele olduğunu, askerin İbrahim'i tuttuğunu, Hamza Bey tarafindan yakalanan Ali Bey'in sultana gönderildiğini ve sultanın ona Sofya sancağı ile bir kız kardeşini verdiğini bildirmiştir. Ancak Bengi Ali ile Ali’ yi karıştırdığı anlaşılmaktadır.

70 Neşri, bu seferin tarihini 1434-1435 olarak vermiştir. Karamanoğlu İsa Bey'in de sultanın yanında olduğunu belirtmiştir. Mehmed Neşri, a.g.e., s. 617. İbrahim Bey dönemi Osmanl-Karamanl ilişkileri için bkz. Gök, "İbrahim Bey Devri", ss. 107-121.

$71 \mathrm{Bu}$ seferin bir at yüzünden ortaya çıktığı da anlatılır. Karamanoğlu ile Dulkadiroğlu arasında bir at yüzünden düşmanlık ortaya çıkmıştı. İbrahim Bey bu atı isteyince verilmemiş, o da Varsak Cemaatinden bedavi Urbanı'ya atı çaldırmıştı. Bu durum Süleyman Bey tarafindan sultana haber verilince bir mektup gönderilerek at istendi. Karamanoğlu elçiye uygunsuz sözlerle cevap verdi. Durum haber verilince sultan orduyu toplayıp önce Akşehir ardından Konya üzerine geldi. 
tiler. Durumu gören İbrahim Bey, hemen Mevlâna Hamza’yı gönderdi. Mevlâna Hamza, İbrahim Bey'in pişman olduğunu ve af dilediğini ifade ederek, Hamidili'ni de bıraktı. Sultan Murad, Hamidili'ni, İsa Bey'e verdiğini ifade etmişti. Sultan da Mevlâna Şükrullah'ı göndermiştir72. "Karamanoğlu, hanedanmmızn beslemelerindendir. Ne denli yüksekliğe erişse, yine zayıf bir kulunuzdur. Az günah için, çok ceza vermek mürü̈vet değildir." diyen Mevlâna Hamza'nın talebi uygun görülmüştür ${ }^{73}$. Fakat kendi beyi hakkında bu sözleri söylemesi pek mümkün görünmemektedir. Beyini affettirmek isteyen bir elçi olduğu aşikâr ancak bu kadar aşağılaması da beklenir bir durum değildir.

Neşri’ye göre de görüşmelerde Karamanoğullarını Mevlâna Hamza ${ }^{74}$, Osmanlıları ise Mevlâna Şükrullah temsil etmiştir ${ }^{75}$. İdris-i Bitlisî̀ ye göre ise durumun vahametini anlayan İbrahim Bey pişman olarak Sultan Murad'ın kız kardeşi ile Mevlâna neslinden Arif Çelebi'yi gönderdi. Sultanın Mevlevilere muhabbetini bildiğinden onun şefaatinin kabul olacağını biliyordu. Kız kardeşinin isteği üzerine onu bağışladı. İbrahim Bey hayatta olduğu müddetçe nifak çıkarmayacak, Hamidili'ni geri verecekti. Osmanlılar da aldıkları yerleri geri vermişlerdi ${ }^{76}$. Sul-

Sonra Beyşehir'e girildi. İdris-i Bitlisî, a.g.e., ss. 355-356. Benzer şekilde Dukas da bu seferin bir at nedeniyle yapıldığını anlatmıştır: Osmanlı hükümdarı, Karaman beyinden bu meşhur atı istemiş olumlu cevap alamayınca Karaman topraklarına girerek Akşehir ve Beyşehir’i zapt etmiştir. Karaman beyi hiçbir şey yapamayacağını anladığından en şerefli adamlarından elçiler, yeterince para ve adı geçen atı gönderdi. Ayrıca Murad'ı aldığı yerleri de ona bırakmış ve bunlarla yetinip geri gitmesi en büyük isteğiydi. Dukas, İstanbul'un Fethi Dukas Kroniği (1341-1462), (Çeviren: V. Mirmiroğlu), Kabalcı Yayınclık, İstanbul 2013, ss. 141-142. At meselesi hakkında bkz. Hoca Sadeddin Efendi, a.g.e., ss. 186-187. Jorga, at meselesinin tarihini 1430 olarak vermiş̧ir. Jorga, a.g.e., s. 341 .

72 Aşıkpaşazade, a.g.e., ss. 128-129.

73 Solak-zâde, a.g.e., s. 225.

74 "Ülkesindeki hakimlerin gözbebeğgi ve yönetim işlerini düzene koyanlarn önderi olan Mevlâna Hamza'y özür ve affi dilemek, cihana vekar ile hükmeden padişahın hoşgörüsüne sığrnmak için yüce otağın eşiğine yollad."” Hoca Sadeddin Efendi, a.g.e., s. 189. Mevlâna Hamza'nın sultanla olan konuşması için bkz. Hoca Sadeddin Efendi, a.g.e., ss. 189-190. Osmanlı-Karaman mücadelesinde Şeyh Ali Semerkandi arabulucu görevini üstlenerek, müritlerinden Molla Hamza-i Karamani’yi, Karamanoğlu İbrahim adına Osmanlı sultanı II. Murad'a elçi olarak göndermiştir. Mercan, a.g.m., s. 72. Mevlâna Hamza hakkında bkz. Mecdi Mehmed Efendi, Hadâ'iku'ş-Şakẩik, (Hazırlayan: Abdülkadir Özcan), Çağrı Yayınları, İstanbul 1989, ss. 120-121.

75 Mehmed Neşri, a.g.e., s. 619.

76 İdris-i Bitlisî, a.g.e., s. 357. Molla İdris Tarihi'nde bu elçilik görevi Molla Hamza yerine, Mevlâna Gelaleddin Rumi torunlarından Ulu Arif Çelebi kaydedilmiştir. Mevlâna soyuna karşı Sultan Murad'ın bağlllığı her tarafta duyulmuş olduğundan, Karamanoğlu' nun onu şefaatçi gönderdiğini sözlerine eklemiştir. Hoca Sadeddin Efendi, a.g.e., s. 191. İbrahim Bey, şefaatçi olarak Mevlâna 
tan Murad, Hamidili arazisini İsa Bey’e verdiğini bildirdi. Ancak İsa Bey, mücadelede öldü ${ }^{77}$.

İbrahim Bey bir daha itaatten çımayacă̆ına dair yeminle Mayıs-Haziran 1437 tarihinde söz vermiştir ${ }^{78}$. Konuyla ilgili kısmı barış için gönderilen heyetin, Mevlâna Hamza ile İbrahim Bey'in eşi ve II. Murad'ın kız kardeşi İlaldı Sultan'dan oluşmasıdır. Ruhi olayı şöyle anlatmıștır: "Karaman-oğh İbrahim Begün avreti ki Sultan Muradun kız karndaşı idi, Mevlâna Hüdavendigar oğluyla gelüb șefáat idüb Sultan Murad dahı anun şefa atin kabul idüb"79. Burada yapılan anlaşmada Mevlâna Hamza ismi çok öne çıkmakla birlikte İlaldı Sultan'ın en az onun kadar etkili olduğu söylenebilir. Gazavat ta isim vermeden ulemanın gönderildiği ve onların Karamanoğlu'nun pişman olduğunu ilettiği anlatılır. Padişah ise şöyle düşünüyordu: "Ya an ele getürüb başın keserim ve yahud başın alur bir gayn iklime gider, gayn dürlü olmaz deyüb elçileri taşra edïb kovdular." Ancak paşaların araya girmesiyle bundan sonra fitne yapmaması şartıyla suçu affedildi ve toprakları bağışland $\iota^{80}$. Dukas ise sulh için giden elçilerle birlikte Murad'ın kız kardeşinin kocasının ricasının yerine getirilmesini isteyen bir mektup gönderdiğini belirterek farklı bir bilgi vermiştir ${ }^{81}$.

1442-1444 yılları arasındaki Osmanlı-Karamanlı mücadeleleri genelde birbiriyle karıştırılmıştır. Kronikler ve mevcut araştırmalardaki bilgiler de konuyu daha girift hale getirmiştir. Ancak genel anlamda Osmanlıların Karamanoğulları üzerine 1442-1443 ve 1444 ylllarında harekât gerçekleştirdiği anlaşılmaktadır. Nitekim Aşıkpaşazade'nin bahsettiği 1443 olayıdır ${ }^{32}$. Ona göre; Osmanlı askerinin

Celaleddin Rumi’nin torunu Ulu Arif Efendi’yi gönderdi. Topraklarını geri İbrahim Bey’e verdi. Bir rivayete göre de şefaatçi olarak Karamanoğlu’nun müftüsü Mevlâna Hamza Karamani geldi. Sultan Murad anlaşma için kendi tarafindan Mevlâna Şükrullah’ı gönderdi. Bu seferde, İbrahim Bey'in kardeşi İsa Bey, Sultan Murad'ın yanındaydı. Müneccimbaşı Ahmed Dede, Müneccimbaşı Tarihi, C. I, (Hazırlayan: İsmail Erünsal), tarihsiz, s. 223.

77 Halil İnalcık, Kuruluş Dönemi Osmanl Sultanlan 1302-1481, ISAM Yayınları, 2013, s. 167; Uzunçarşıll, Anadolu Beylikleri, s. 24. İnalcık, "Murad II", s. 606.

Ruhi, "Rûhî Târîhi”, (Hazırlayanlar: Halil Erdoğan Cengiz-Yaşar Yücel), Belgeler, C. XIV, S. 18, TTK Yayınları, Ankara 1992, s. 439.

Gazavât-ı Sultân Murâd b. Mehemmed Hân, (Yayınlayanlar: Halil İnalcık, Mevlûd Oğuz), TTK Yayınları, Ankara 1989, ss. 6-7.

81 Dukas, a.g.e., s. 143.

82 Bu seferler hakkında değerlendirmeler için bkz. Gazavât-ı Sultân Murâd b. Mehemmed Hân, s. 84, not 7. 1425 yılında Edirne'de doğan Şehzade Alaeddin Ali, Haziran 1443’te ölmüştür. Babası ile 1443 yılındaki Karaman seferine katılmış, Amasya'ya dönünce vefat etmiştir. Bir rivayete göre attan düşerek ölmüş̧ür. Doğum tarihini farklı veren Alderson da ölüm tarihini aynı 
bozguna uğradığını işiten Karamanoğlu, Emirdağı ve Beypazarı'na ${ }^{83}$ gelip buraları yağma etti ve andını bozdu. Bunu duyan Sultan Murad, Konya'yı yağma etti. Karamanoğlu kaçıp Taşili'ne sığındı. Karamanoğlu hatununu ve veziri Sürur'u ${ }^{84}$ gönderdi. Bunlar; "Karamanoğlu kendisine layıkı etti. Hak Taala yannda yüzünü kara eyledi. O halde sen kerem et, lïtfet. Bu sefer dahi bunun küstahlğgna bakma. Buna yüz karah̆̆ğ derler. Suçunu bildi. Suçunu affeyle." deyince sultan, Sürur'a kefil misin diye sordu. Sürur cevabında evvelki hatasında ben yoktum, bu hatası da Turgutoğullarından oldu, deyince Karamanoğlu' nun suçunu affetti ${ }^{85}$. Neşri ise aynı olayı Karamanoğlu İbrahim Bey, kafirlerin Osmanlı'yı yendiğini işitince Beypazarı'na varıp türlü işler ettiler. Kafir dahi kafirliğince o işi etmezdi ${ }^{86}$ demiştir. Neşri olayın devamını ise şöyle anlatmıştır:

"Karamanoğlu'nun halka ettiği hakaretleri işiten Sultan Murad, Konya'ya geldi. Karamanoğlu Taş'a kaçtı. Alaeddin Çelebi babasıyla birlikte Larende'yi harap etti. O vakte kadar Osmanl'dan hiçbir bey bu kadar zulmetmemişti. Bunca mezalime Karamanoğlu İbrahim Bey sebep olmuştu. Karamanoğlu'nun hatunu ki, Sultan Murad'ın kız kardeşiydi. Onunla veziri Kara Server'i sultana gönderdi. Eşi 'Çün gelip benim evimi böyle harab edecek idin, beni buna verip niderdiniz?’ deyip ağladı. Kara Server

yılda göstermiştir. Bkz. Öztuna, a.g.e., s. 129; Alderson, a.g.e., s. 238. Bu sefere katılan Şehzade Alaeddin'in ölümü, olayın 1443 yılında olduğunu net bir şekilde ortaya koymaktadır. Bunun yanında, Aşıkpaşazade de olayın tarihi verilmemiş ancak olayların kronolojik anlatımına dikkat edilirse bu seferin Varna Savaşı'ndan önce olduğu anlaşılmaktadır. Yine oğlunu tahta geçirmeden önce bu seferden bahsedilmiştir. Başka bir kanıt ise Karamanoğullarının Kula Şahin Paşa'nın yenilgisi üzerine Osmanlı topraklarına saldırmalarıdır. Bütün bu nedenler bahsi geçen seferin 1443 yllında olduğunu göstermektedir.

83 Zaifi'nin Gazâvat-ı Sultân Murâd Hân adlı eserinde; Sultan Murad gazaya gideceğinde Karamanoğlu’nun Sivrihisar'a saldırdığı, Karaoğlu ve Yapaoğlu adlı kişilerin iki bin askerle Karaman askerini yendiği ve Karamanoğlu'nun Beypazarı'na saldırması anlatılmıştır. Zaifi'nin, "Geçen ynl geldi Begşsehrini yıkd... Bu ynl ol Begbazârnna kim irmiş... Geȩen ynl kim ben anuñla barı̧sdum..." ifadelerini kullanması 1443 ve 1444 yıllarında Karaman üzerine sefer yapıldığını doğrulamaktadır. Mehmet Sarı, Gelibolulu Zạ̧̨i Muhammed Gazâvat-ı Sultân Murâd Hân İnceleme (Ses Değissmeleri, Benzeşmeleri ve Uyumlar) Metin-Sözlük, İstanbul Üniversitesi Sosyal Bilimler Enstitüsü Yayımlanmamıs Doktora Tezi, İstanbul 1994, s. 205-208.

84 Kaynaklarda Sürur ya da Server olarak geçen aynı kişidir. İbrahim Bey'in veziridir. Server Ağa aynı zamanda hayırsever bir kişiliğe sahipti. Nitekim Konya'da cüz okunmak şartıyla 17 dükkânın gelirini vakfetmiş ve Konya'da üç yerde çeşme yaptırmıştır. TKGMA, TD 584, v. 14b, 28a.

85 Aşıkpaşazade, a.g.e., ss. 140-141.

86 Mehmed Neşri, a.g.e., s. 637. Neşri, 30 Nisan 1443 tarihinde, harekâtın bittiğini gösteriyorsa da muhtemelen yaz boyu sürmüş olmalıdır. Murad, bu harekâttan az sonra Alaeddin'in ölüm haberini aldı. Colin Imber, Varna Savaşı, (Çev. Ayda Arel), Kitap Yayınevi, İstanbul 2007, s. 35. 
de önceki hatasında ben yoktum. Bu hatasına rızam yoktur. Bu, Turgutoğullarından dolayı oldu. Hünkara suçumu affettir diye beni gönderdi." ${ }^{87}$

İdris-i Bitlisî ise Mevlâna neslinden bir kişiyi elçilik heyetine eklemiş ve olayı şöyle anlatmıştır:

“846/1442-43 yılında Karamanoğlu’ndan intikam almak için üzerine yürüyen Sultan Murad, oğlu Amasya'da bulunan Şehzade Alaeddin'i de çağırdı. Karaman toprakları yağma edildi, karşı koyamayacağını anlayan İbrahim Bey geri çekildi. Hanımı, vezir-i azamı Hoca Server’i ve Mevlâna hafidini Sultan Murad'a gönderdi. Çünkü hemşire-i sultânî biraderinin katında gayet ile aziz ve muhterem idi. Bu görüşmelerde sultana düşmanına gücün yettiğinde kudretine şükür eyle demişti. Sultan, İbrahim Bey’in ahd isteğine güvenmedi ancak kız kardeşinin hatırı için ahd yenilenmişti." ${ }^{88}$

Bahsedilen tarihteki hadise diğer kaynaklarda da benzer şekilde anlatılmakla birlikte İlaldı Sultan'a ait tanımlamalar olduğu için konuyla ilgili şu bilgiler dikkati çekmiştir.

"Karaman ülkesine giren ordu, buraları yağmaladı. Bu tarihe kadar hiçbir İslam beldesi yağmalatılmamıştı. Karamanoğlu, Taşili’ne kaçtı. Hediyelerle birlikte veziri Server Bey'i sultana gönderdi. Padişahın kız kardeşi olan üstün değerli eşini de suçunu bağışlatmak için sultanın yanına yollamış bulunuyordu. Bazı tarihçilere göre Sarı Yakub, Molla İdris'e göre ise Ulu Arif Çelebi şefaatçi olarak gönderilmişti. Sultanın temiz bir inciyi andıran kız kardeşi, eşinin suçlarının bağışlanmasını diledi. Döktüğü gözyaşları, hıçkırıklar ince kalpli sultanı yumuşattı. Af ve kerem yüzüne dönerek onun şefaat perdesini eşinin edepsizliklerine örtü eyledi. İffet köşkünün perdeleri ardında oturan bu hatunun gözyaşları iyi ahlak sahibi padişahın şefkat damarlarını kabartmakla, Hoca Server'e tarizlerle dolu güzel bir konuşma yapt1." $" 99$

Mehmed Neşri, a.g.e., s. 643. Hân, s. 85, not 7; Dukas, a.g.e., s. 152; İnalcık, "Murad II", s. 608; Inalcık, Osmanl Sultanlan, s. 169; Uzunçarşlı, Osmanl Tarihi, ss. 421-422; Babinger, a.g.e., s. 40.1443 yılı Karaman seferinde o zamana kadar yapılmayan tahribat yapıldı. Karamanoğlu İbrahim Bey hak iddia ettiği yerlerden vazgeçmek ve Osmanlı tabiliğini kabul etmekle sulhu elde edebildi. Ínalcık, Fatih Devri, s. 56.

Hoca Sadeddin Efendi, a.g.e., s. 206-207. Sultan Murad'ın Server'e konuşması hakkında bkz. Hoca Sadeddin Efendi, a.g.e., s. 207. Server Ağa, İbrahim Bey'in veziriydi ve çok sayıda vakıf bırakmıştır. Babasının adı Abdullah’tı. Hamit Şafakcı, "Şeyh Hocenti Zaviyesi", Selçuk Üniversitesi Türkiyat Araştrmalan Dergisi, S. 39, Konya 2016, ss. 5-6. 
Görüşmeler için veziri Server Bey'i hediyelerle Sultan Murad'a gönderdi. Özellikle padişahın kız kardeşini de göndererek, şefaat ricasını iltimas eylemişti. Suçlarının bağışlanmasını isteyince, kız kardeşlerinin hatırına riayet için olacak, bağışlandı ${ }^{90}$. Yaptıklarından pişmanlık duyarak veziri Server Bey’i, müftüsü Sarı Yakub'u -bir rivayete göre Mevlâna'nın torunlarından Arif Çelebi'yi- ve sultanın kız kardeşi olan zevcesini af dilemeleri için sultana gönderdi9 ${ }^{91}$. Nitekim bu seferde dikkati çeken nokta Osmanlı kuvvetlerinin çok sert davranması ve bir İslam beldesinin yağmalanmasına müsaade edilmesiydi. Zira yapacağı seferde arkasında güçlü ve kendisine baş kaldırabilecek bir beylik istemiyordu. Yine Rumeli’ndeki durum üzerine sulh yapıldığı da gözden kaçmamalıdır. Zira aciliyet ya da öncelik oradaydı. Yapılan barış görüşmelerine İbrahim Bey'in eşi İlaldı Hatun ile veziri Server Ağa'nın katıldığı konusunda bütün yazarlar hemfikirdir. Ancak Osmanlı affedici gösterilmiş ise de Osmanlı'yı böyle davranmaya iten zorunluluklar unutulmamalıdır.

1444 baharında Karamanlılar; Sivrihisar, Beypazarı, Ankara ve Karahisar’a kadar ilerlemiş, Akşehir ve Beyşehir bölgesini işgal etmişti. Edirne Segedin Antlaşması yeminle tasdik edilip barış imzalanınca Sultan Murad, dört mezhepten fetvalar alarak Karamanoğullarına karşı harekete geçti. Karamanoğlu, II. Murad'ın tekrar üzerine geldiğini görüp durumun vahametini anlayınca tekrar adamlar gönderip pişman olduğunu bildirdi. Padişah, onu bağışlayıp topraklarını geri verdi. Bu hadise, Karamanoğlu ile Temmuz 1444 tarihinde yapılan Yenişehir Barış Antlaşması ile sonuçlanmıștır ${ }^{92}$. Ahidnâme, Sevgendnâme veya musâlaha olarak adlandırılan Sultan II. Murad'a İbrahim Bey'in verdiği belgede; İbrahim Bey'in her yıl bir oğlunu askeri ile birlikte Osmanlı padişahının hizmetine vermeyi taahhüt etmiştir. Bir diğer husus ise İbrahim Bey'in ahdini bozmayacağına dair defalarca yemin etmesiydi ${ }^{93}$. Bazı çalışmalarda İbrahim Bey’in eşi ile veziri Server Ağa’yı

90 Solak-zâde, a.g.e., s. 231.

91 Müneccimbaşı Ahmed Dede, a.g.e., s. 231.

92 İnalcık, "Murad II", s. 608; İnalcık, Osmanh Sultanları, s. 170; Uzunçarşıll, Osmanh Tarihi, s. 428; Gazavât-ı Sultân Murâd b. Mehemmed Hân, s. 36, 104 not 33a; Imber, Varna Savaşı, s. 48. Karamanoğlu'nun yağma ve tahripleri üzerine yapılan seferde, II. Murad harp yapmamış büyük fedakarlıklarla barış imzalamıştır. Hamidili topraklarını İbrahim Bey’e bırakmıştır. Murad arazi sorunlarını bağlarken cömert davranmış ve ona, aralarında 1437'de ele geçirdiği Akşehir ve Beyşehir'in de olduğu birçok sınır şehrini bırakmıştır. İnalcık, Fatih Devri, s. 15; Imber, Varna Savaşı, s. 48.

93 Alaaddin Aköz, "Karamanoğlu II. İbrahim Beyin Osmanlı Sultanı II. Murad'a Vermiş Olduğu Ahidnâme", Türkiyat Araştırmalan Dergisi, S. 18, Konya 2005, ss. 164, 169. II. Murad, batıda barışı bağladıktan sonra Anadolu'da Karamanoğlu ile bir sevgendnâme imzaladıktan sonra oğlu II. Mehmed lehine tahttan çekilmek istiyordu. İnalcık, Fatih Devri, s. 14. 
sulh için gönderdiği Aşıkpaşazade'nin 1443 yılı ile ilgili yukarıda verilen bilgilerden hareketle söylenmiştir. Diğer kaynakların teyit etmediği bu bilgi, yıl karışıklığı olarak değerlendirilmelidir. Zira barış için giden heyet, Karaman'ın uluları olarak adlandırılmıştır ${ }^{94}$. Bu ifadeden onların gitmesinin de bir ihtimal olduğu anlaşılmaktadır. Ancak isim zikredilmediği için ihtiyatlı yaklaşmak gerekir ${ }^{95}$.

Fatih döneminde meydana gelen anlaşmazlıklar nedeniyle ise Karamanoğlu İbrahim Bey, Mevlâna Veli'yi barış için göndermiştir. Kassaboğlu Mahmud Bey’in önünde sultana isyan etmemeye yemin etti. Ilgın sınır oldu. Beyşehir, Kırşehir ve Seydişehir gibi şehirler Osmanlılara kaldı ${ }^{96}$. Ayrıca sefer esnasında kuvvet göndermek ve kızını Fatih'e vermek şartlarıyla anlaşıld $\imath^{97}$.

\section{Sonuç}

Evlilikler, düşmanlara karşı bir tedbir veya ittifak olarak değerlendirilebilir. Zira ilgili tarafı Osmanlı tarafına çekmek amaçlanmış olmalıdır. Batı’ya doğru yapılacak seferlerde tarafsız kalmasını temin için de olabilir. Bu evliliklere rağmen

Uzunçarșll, Osmanh Tarihi, s. 429; Jorga, a.g.e., s. 342; Alaattin Aköz, "İbrahim Bey (Tacüddin/ Sarimüddin) (1423-1464)", Konya Ansiklopedisi, C. IV, Konya Kültür A.Ş. Yayınları, Konya 2012, s. 317. Zaifi, seferden sonra barış yapmak için gelen heyeti “...Karamanuñ ulular irişdi...” diyerek anlatmıştır. Sarı, a.g.t., s. 214. Benzer şekilde sultana karşı çıkamayacağını anlayan Karamanoğlu'nun hediyelerle birlikte Karaman'ın ulularını gönderip af dilediği, sultanın onları affettiği ve kısa bir süre sonra tahtı oğluna bıraktığı anlatılmıştır. Gazavât-ı Sultân Murâd b. Mehemmed Hân, s. 36.

95 Nitekim Oruç Bey, “... Karaman-oglı İbrâhîm Beg kaçup gidüp, âkıbet efdalü’l-ulemâ ve’l-fudalâ Hazret-i Mevlânâ Saru Ya'kub dirler ol azîz geldi. Gâyet ululardan idi. Karaman-oglı İbrâhîm Beg Saru Ya‘kub’ı gönderüp girü sulh u musâlaha olunup, Sultan Murâd Han andan gelüp yeniçeriye destûr virüp ve sâyir halka dahı destûr virüp, kendüsi begligini terk idüp, Ma'nisa'da oturup tahtını oglı Sultân Mehemmed Han'a ısmarlayup ...” demiştir. Oruç Beğ Tarihi (Giriş, Metin, Kronoloji, Dizin, Tipkıbasım), (Haz. Necdet Öztürk), Çamlıca Yayınları, İstanbul 2008, s. 64.

İbn Kemal, a.g.e., ss. 16-17.

97 Tekindağ, "Son Osmanl-Karaman Münasebetleri", s. 45. Karaman emirleri adamlarından birini göndererek "Rum sultanı, kendi halasının oğulları olan Muhammed ile Pir Ahmed Beğ b. İ̉rahim Beğ'e karşı üstünlük ve baskı kurduğu; onların beldelerinin ve vilâyetlerinin çoğunu yönetimi altına aldığı; ülke alanını onlara dar yaptığı haberini ulaştırdı. Pir Ahmed Beğg, Sultan Muhammed'in halasının kızı olan kendi annesini yardım ve destek istemek için Sahib Kıran'ın huzuruna gönderdi. Beni de durumu padişaha arz etmek için onun hizmetinde görevlendirdi. Annesi yolda Hakk'ın rahmetine kavuştu." Onları desteklemeye karar verdi. Ebu Bekr-i Tihranî, a.g.e., s. 361. 1471 yılı olayları anlatılırken aktarılan bilgilerden Illaldı Hatun'un Uzun Hasan'dan yardım istemeye gittiği anlaşılmaktadır. Hayatı Karamanlı ve Osmanlı arasında arabuluculukla geçen İlaldı Hatun'un oğlu adına yardım istemeye giderken yolda ölmesi, bütün yaşamını anlatan bir hadise gibidir. Sultan Muhammed'in halasının kızı olan kendi annesi ifadesi yanlıştır. Zira İlaldı Hatun'un Fatih'in halası olduğu yukarıda açıklanmıştır. 
kısa bir süre içerisinde düşman olabilecek potansiyele sahip oldukları da bilinmekteydi. Karamanoğlu açısından bakıldığında ise beyliğin başına geçmek için güçlü bir destekçi temin edilmiş oluyordu. Dolayısıyla her iki taraf açısından da evlilik siyasi amaçlar için araç olarak kullanılmıştır. İbrahim Bey yaptığı bu evlilik sayesinde Sultan Murad'ın desteğini almıştır. Kardeşlerinin de kendisini desteklemesi üzerine amcasıyla mücadele ederek Karaman tahtına oturabilmiştir.

Karamanoğlu İbrahim Bey'in eşi İlaldı Hatun, Çelebi Mehmed'in kızıdır. Evlendikten sonra Konya'ya gelen İlaldı Hatun, burada bir darulhuffaz yaptırmıştır. Kur'an-1 Kerim okunan ve öğretilen kurumda, hafizlar yetiştirilmiştir. Vakfin Şadi Bey Hamamı'ndaki hissesinden ve hamamın karşısındaki dükkanlardan gelirleri vardı. Bu gelirler, aydınlatmaya ve vakıftaki görevlilere harcanıyordu. Darulhuffazda mütevelli, nazır, imam, müezzin ve cüzhan ile eğitim alan hafızlar görev almıştır.

Karamanlıların saldırısına rağmen her seferinde anlaşma yapılmasını sadece İlaldı Sultan'ın II. Murad'ın kardeşi olmasına bağlamak yanlış olur. İlaldı Hatun, Osmanlı-Karamanlı mücadelesinde eşinin yani Karamanoğullarının tarafını tutmuştur. Ama daha önemli olan konu, İbrahim Bey her zor durumda kaldığında bölgenin en seçkin ulemasıyla birlikte eşini de göndermiştir. Bu anlamda İlaldı Hatun, bir arabulucu olarak görev almıştır. Ancak Sultan Murad'ın sadece onun hatırı için İbrahim Bey’i bağışladığını söylemek abartı olur. Zira Şahruh'un Anadolu'ya bakışı, Balkanlardaki nazik durum yani konjektürel siyasi yapı düşünüldügünde, aksi bir tavır takınmış olsaydı, cepheyi genişletmekten başka bir şey yapmamış olacaktı. Ama hem İbrahim Bey'e gereken dersi verip hem de onun bütün yaptıklarına rağmen alicenaplık gösterip affetmek, düşmanın gücünü azaltmanın yanı sıra İslam dünyasında sempati ile bakılan bir Osmanlı ortaya çıkarıyordu. Zira Osmanlı hep mecbur kaldığı için Müslüman Karamanoğulları üzerine gitmişti. Ama Karamanoğulları hep arkadan vuran ve düşmanla iş birliği yapan bir beylik imajina kendiliğinden bürünüyordu.

Tahrir defterlerinde İlaldı Hatun yazılırken İbrahim Bey'in eşi olarak değil de Çelebi Mehmed'in kızı olarak yazılmıştır. Vakfin Karamanoğulları döneminde kurulduğu bilinmesine rağmen bunun bilinçli olarak yazıldığı izlenimi vardır. Nitekim Osmanlı kroniklerinde İbrahim Bey'in Osmanlı neslinden gelen çocukları yerine cariyeden doğma İshak'ı tercih etmesi anlatılır. Ancak Osmanlı sultanlarının annelerinin de farklı beyliklerden ya da milletlerden olmasını aynı mantıkla açıklamak güçtür. $\mathrm{O}$ halde bu tür ifadeleri belirleyen devletin maddi ve manevi 
gücüdür. Günümüzde de güçlü olan devletlerin zayıf olanlara istediğini söylediği görülmektedir. Ancak ifade ettiği şeyin kendisinde olması durumunda siyasi gücünden dolayı işin içinden kolayca çıkabilmektedir.

İlaldı Hatun, mücadele halindeki iki taraf arasında kalan her iki hanedana da hisım olan bir kadındı. Ancak 1476 yllından itibaren eldeki mevcut Osmanlı kaynakları İlaldı Hatun'u özellikle Mehmed'in kızı olarak yani bir sultan olarak yazmışlardır. Dolayısıyla Osmanlı tarafina geçen oğullarına gelebileceği en yüksek makamın verilmesi de bu bakış açısının bir göstergesidir. Zira onlar Osmanlıdır.

1437 ylındaki görüşmelere Mevlâna Hamza ile İlaldı Hatun katılırken 1443'te Server Ağa ile Illaldı Hatun barış görüşmelerinde bulunmuştur. 1444 ylında ise Karaman'ın önde gelenleri görüşmelere katılmıştır. 1451 yllında ise barışı tesis etmek için Mevlâna Veli görevlendirilmiştir. İbrahim Bey döneminde Osmanlı-Karamanlı mücadelelerinin ardından sulh tesisi için giden heyetler ya devletin önemli kademelerindeki görevliler ya da devrin önemli alimleriydi. Ancak her iki gruba da eşlik eden İbrahim Bey'in eşi ve II. Murad'ın kız kardeşi olan İlaldı Hatun'du. Kocasıyla kardeşi arasında bir kadının arabuluculuğu, insani olarak düşünüldügünde gerçekten zor bir durum. Çünkü kişinin birini tercih etmesi gerekecekti. Dolayısıyla savaş ile barışın, kardeş ile kocanın ve Osmanlı ile Karamanlı'nın tam ortasında bir figürdü Ilaldı Hatun. Ancak genel anlamda değerlendirildiğinde ikinci ifadeleri tercih ettiği söylenebilir. İlaldı Hatun'un görevi, mesajı iletmek ve onun kardeşliğinden istifade ederek durumun nezaketini anlatmaktı. Zira burada İbrahim'e zarar verirken bana ve çocuklarıma da zararın olacak mesajı verilmiş olmalıdır.

İncelenen konu yanında İncu Hatun'un Çelebi Mehmed'in kızı olduğu, Karamanoğlu Mehmed Bey'le evlendiği ve İbrahim Bey'in analığı olduğu da ortaya çıkmıştır. Osmanlı ailesinden olan Nefise Hatun'un torunu olan İbrahim Bey, Çelebi Mehmed'in kızı İlaldı Hatun ile evlenmiştir. Bu evlilikten altı erkek ve bir kız çocukları olmuştur. Kızları, Fatih Sultan Mehmed'le evlenmiştir. Birbirine aile bağlarıyla bağlı olan kişilerin mevzubahis devletleri olunca tamamen yönetici vasıflarıyla hareket ettikleri anlaşılmaktadır. Bu çalışmada Çelebi Mehmed'in sekiz kızı olduğu anlaşılmıştır. Bunların kimlerle evli olduğu tespit edilmiştir. Ancak kızlardan birisinin ismi bilinmemektedir. Ayrıca Karamanoğlu İbrahim Bey, İlaldı Hatun'dan önce bir cariye ile evliydi. Ancak cariye olan eşi 1432'de öldürülmüştür. Bu eşinden Mehmed ve İshak adlı oğulları olmuştur. 1471 yılında, oğullarına yardım etmesi için Uzun Hasan'a giden Illaldı Hatun, yolda ölmüştür. Babaları için yaptığı arabuluculuğu oğulları için de yapmaya çalışmıştır. 


\section{KAYNAKLAR}

\section{Arşiv Kaynakları}

Başbakanlık Osmanlı Arşivi (BOA) Tapu Tahrir Defterleri (TT.d): 63, 455.

387 Numarah Muhâsebe-i Vilâyet-i Karaman ve Rûm Defteri (937/1530) I, Devlet Arşivleri Genel Müdürlüğü, Osmanlı Arşivi Daire Başkanlığı Yayınları, Ankara 1996.

Konya Şeriye Sicilleri (KŞS): 53, 69.

Tapu Kadastro Genel Müdürlüğü Arşivi (TKGMA) Tapu Tahrir Defterleri (TD): 565,584 .

Topkapı Sarayı Müzesi Arşivi Belgeleri (TSMA.E): 748/52, 754/63.

Vakıflar Genel Müdürlüğü Arşivi Defterleri (VGMA.d): 460, 728.

Vakıflar Genel Müdürlüğü Arşivi Hurufat Defterleri (VGMA, HD): 1107, 1140.

\section{Kitaplar, Tezler ve Makaleler}

Akgündüz, Ahmed, Tüm Yönleriyle Osmanlida Harem, Timaş Yayınları, İstanbul 2012.

Aköz, Alaaddin, "Karamanoğlu II. İbrahim Beyin Osmanlı Sultanı II. Murad'a Vermiş Olduğu Ahidnâme", Türkiyat Araștrmalan Dergisi, S. 18, Konya 2005, ss. $159-178$.

Aköz, Alaattin, "İbrahim Bey (Tacüddin/Sarimüddin) (1423-1464)", Konya Ansiklopedisi, C. IV, Konya Kültür A.Ş. Yayınları, Konya 2012, ss. 316-318.

Alderson, Anthony Dolphin, Bütün Yönleriyle Osmanh Hanedanı, (Tercüme eden: Şefaettin Severcan), İz Yayıncılık (Yeni Şafak), Tarihsiz.

Aşıkpaşazade, Aşıkpaşaoğlu Tarihi, (Hazırlayan: Atsız), MEB Yayınları, İstanbul 1970.

Ayverdi, Ekrem Hakkı, Osmanh Mimârîsinde Çelebi ve II. Sultan Murad Devri 806-855 (1403-1451) II, Baha Matbaası, İstanbul 1972.

Babinger, Franz, Fatih Sultan Mehmed ve Zamanı, (Çev. Dost Körpe), Oğlak Yayınlarr, İstanbul 2003. 
Baltacı, Cahid, XV-XVI. Asırlarda Osmanl Medreseleri, C. I, M.Ü. İlahiyat Fakültesi Vakfi Yayınları, İstanbul 2005.

Bertrandon De La Broquiére'in Denizaşın Seyahati, (Editör: Ch. Schefer), (Çeviren: İlhan Arda), Eren Yayınları, İstanbul 2000.

Bozkurt, Nebi, "Dârülkurrâ", DİA, C. VIII, 1993, ss. 543-545.

Coşkun, Fahri, 888/1483 Tarihli Karaman Eyaleti Vakıf Tahrir Defteri, İstanbul Üniversitesi Sosyal Bilimler Enstitüsü Yayımlanmamış Yüksek Lisans Tezi, Ístanbul 1996.

Dukas, İstanbul'un Fethi Dukas Kroniği (1341-1462), (Çeviren: V. Mirmiroğlu), Kabalcı Yayıncılık, İstanbul 2013.

Ebu Bekr-i Tihranî, Kitab-ı Diyarbekriyye, (Çev. Mürsel Öztürk), TTK Yay., Ankara 2014.

Erdoğru, Mehmet Akif, "Murad Çelebi Defteri: 1483 Yılında Karaman Vilâyetinde Vakıflar-I-", Tarih Incelemeleri Dergisi, XVIII, S. 1, 2003, ss. 119-160.

Erdoğru, Mehmet Akif, "Murad Çelebi Defteri: 1483 Yılında Karaman Vilâyetinde Vakıflar-II-”, Tarih Incelemeleri Dergisi, XVIII, S. 2, 2003, ss. 99-140.

Gazavât-ı Sultân Murâd b. Mehemmed Hân, (Yayınlayanlar: Halil Inalcık, Mevlûd Oğuz), TTK Yayınları, Ankara 1989.

Gök, Bilal, "İbrahim Bey Devri (1423-1464) Karaman-Osmanlı Münasebetleri”, Hikmet Yurdu, C. 5, S. 10, 2012, ss. 107-121.

Gökbilgin, M. Tayyib, XV. ve XVI. Asırlarda Edirne ve Paşa Livası, Vakıflar-Mülkler-Mukataalar, İşaret Yayınları, İstanbul 2007.

Halil Edhem, "Karaman Oğulları Hakkında Vesâik-i Mahkûka", TOEM, S. 13, İstanbul 1330, ss. 821-836.

Halil Edhem, "Karaman Oğulları Hakkında Vesâik-i Mahkûka", TOEM, S. 14, İstanbul 1330, ss. 873-881.

Hoca Sadeddin Efendi, Tacü't-tevarih, C. II, (Hazırlayan: İsmet Parmaksızoğlu), Kültür Bakanlığı Yayınları, Ankara 1979.

İbn Kemal, Tevârih-i Âl-i Osman, VII. Defter, (Hazırlayan: Şerafettin Turan), TTK Yayınları, Ankara 1991. 
İdris-i Bitlisî, Heşt Behişt, C. II, (Hazırlayanlar: Mehmet Karataş, Selim Kaya, Yaşar Baş), Bitlis Eğitim ve Tanıtma Vakfı Yayınları, Ankara tarihsiz.

İnalcık, Halil, Fatih Devri Üzerinde Tetkikler ve Vesikalar I, TTK Yayınları, Ankara 1987.

İnalcık, Halil, Kuruluş Dönemi Osmanlı Sultanlan 1302-1481, ISAM Yayınları, 2013.

İnalcık, Halil, "Murad II", İA, C. VIII, MEB Yayınları, Eskişehir 1997, ss. 598615.

Imber, Colin, Varna Savaşı, (Çev. Ayda Arel), Kitap Yayınevi, İstanbul 2007.

Jorga, Nicolae, Osmanh İmparatorluğu Tarihi 1 (1300-1451), (Çev. Nilüfer Epçeli), Yeditepe Yayınları, İstanbul 2009.

Kahraman, Seyit Ali, XVI. Yüzyıl Başlarnda Karaman Vilâyeti Vakıflan, Kayseri Büyükşehir Belediyesi Kültür Yayınları, Kayseri 2009.

Konyalı, İbrahim Hakkı, Âbideleri ve Kitâbeleri İle Karaman Tarihi Ermenek ve Mut Âbideleri, Baha Matbaası, İstanbul 1967.

Konyalı, İbrahim Hakkı, Âbideleri ve Kitabeleri İle Konya Tarihi, Burak Matbaası, Ankara 1997.

Küçükdağ, Yusuf, Konya Darülkurralarn (1400-1920), Çizgi Kitabevi Yayınları, Konya 2014 .

Lütfi Paşa, Tevarih-i Âl-i Osman, (Hazırlayan: Kayhan Atik), Kültür Bakanlığı Yayınları, Ankara 2001.

Mehmed Neşri, Kitâb-ı Cihan-nümâ, C. II, (Yayınlayanlar: Faik Reşit Unat-Mehmed A. Köymen), TTK Yayınları, Ankara 1987.

Mehmed Süreyya, Sicill-i Osmanî, C. 1, 3, (Hazırlayanlar: Nuri Akbayar, Seyit Ali Kahraman), Tarih Vakfi Yurt Yayınları, İstanbul 1996.

Mercan, İsmail Hakkı, "Şeyh Alâeddin Ali es-Semerkandî ve Menâkıb-nâmesi, Menâkıb-nâmeye Göre Osmanlı Karamanlı Mücâdelesi", XIII. Türk Tarih Kongresi Bildirileri (4-8 Ekim 1999), C. III/1, Ankara 2002, ss. 47-76.

Müneccimbaşı Ahmed Dede, Müneccimbaşı Tarihi, G. I, (Hazırlayan: İsmail Erünsal), tarihsiz. 
Oğuzoğlu, Yusuf, “17. Yüzyılda Konya Şehrindeki İdari ve Sosyal Yapılar”, Konya, (Hazırlayan: Feyzi Halıcı), Güven Matbaası, Ankara 1984, ss. 97-108.

Oruç Bĕg Tarihi (Giriş, Metin, Kronoloji, Dizin, Tipkıbasım), (Haz. Necdet Öztürk), Çamlıca Yayınları, İstanbul 2008.

Öztuna, Yılmaz, Devletler ve Hânedanlar, Türkiye (1074-1990), C. II, Kültür Bakanlığı Yayınları, Ankara 1996.

Pakalın, Mehmet Zeki, Osmanlı Tarih Deyimleri ve Terimleri Sözliü̆ü, C. I, MEB Yayınları, İstanbul 1993.

Peirce, Leslie P., Harem-i Hümayun Osmanl Imparatorluğu'nda Hükümranlık ve Kadınlar, (Çev. Ayşe Berktay), Tarih Vakfı Yurt Yayınları, İstanbul 1996.

Ruhi, "Rûhî Târîhi”, (Hazırlayanlar: Halil Erdoğan Cengiz-Yaşar Yücel), Belgeler, C. XIV, S. 18, TTK Yayınları, Ankara 1992, ss. 359-472.

Sakaoğlu, Necdet, Bu Mülkün Kadın Sultanlar Vâlide Sultanlar, Hâtunlar, Hasekiler, Kadinefendiler, Sultanefendiler, Oğlak Yayıncılık, İstanbul 2008.

Sakaoğlu, Necdet, Bu Mülkün Sultanları 36 Osmanlı Padişahı, Oğlak Yayıncılık, İstanbul 1999.

Sakaoğlu, Necdet, "Mehmed I (Çelebi)", Yaşamlar ve Yaptlanyla Osmanhlar Ansiklopedisi, C. II, Yapı Kredi Kültür Sanat Yayıncılık, İstanbul 2008, ss. 79-82.

Sarı, Mehmet, Gelibolulu Zą̧fi Muhammed Gazâvat-ı Sultân Murâd Hân İnceleme (Ses Değismeleri, Benzeşmeleri ve Uyumlar) Metin-Sözlük, İstanbul Üniversitesi Sosyal Bilimler Enstitüsü Yayımlanmamış Doktora Tezi, İstanbul 1994.

Solak-zâde Mehmed Hemdemî Çelebî, Solak-zâde Tarihi, C. I, (Hazırlayan: Vahid Çabuk), Kültür Bakanlığı Yayınları, Ankara 1989.

Şafakcı, Hamit. "Şeyh Hocenti Zaviyesi", Selçuk Üniversitesi Türkiyat Araştırmalan Dergisi, S. 39, Konya 2016, ss. 1-23.

Şikârî, Karamannâme [ Zamanın Kahraman Karamanîler'in Tarihi ], (Hazırlayanlar: Metin Sözen, Necdet Sakaoğlu), Karaman Valiliği-Karaman Belediyesi Yayını, Istanbul 2005.

Tekindağ, M. C. Şehabeddin, "Son Osmanlı-Karaman Münasebetleri Hakkında Araştırmalar”, Tarih Dergisi, C. XIII, S. 17-18, İstanbul 1963, ss. 43-76. 
Tekindağ, M. G. Şihâbeddin, "Karamanlılar”, IA, C. VI, MEB Yayınları, Eskişehir 1997, ss. 316-330.

Uluçay, M. Çağatay, Padişahlarn Kadınlan ve Kizlan, Ötüken Yayınları, İstanbul 2012.

Uzluk, F. Nafiz, Fatih Deurinde Karaman Eyâleti Vakıflan Fïhristi, Vakıflar Umum Müdürlüğü Neşriyat, Ankara 1958.

Uzunçarşıll, İsmail Hakkı, Anadolu Beylikleri ve Akkoyunlu, Karakoyunlu Devletleri, TTK Yayınları, Ankara 2011.

Uzunçarşıll, İsmail Hakkı, Çandarl Vezir Ailesi, TTK Yayınları, Ankara 1988.

Uzunçarşıll, İ. Hakkı, "Çelebi Sultan Mehmed'in Kızı Selçuk Hatun Kiminle Evlendi”, Belleten, G. XXI, S. 82, 1957, ss. 253-260.

Uzunçarşılı, İsmail Hakkı, "Karamanoğulları Devri Vesikalarından İbrahim Beyin Karaman İmareti Vakfiyesi”, Belleten, G.I, S. 1, II. Baskı, TTK Yayınları, Ankara 1995, ss. 56-164.

Uzunçarşıll, İsmail Hakkı, "Mehmed I”, İA, C. VII, MEB Yayınları, Eskişehir 1997, ss. 496-506.

Uzunçarşılı, İsmail Hakkı, Osmanlı Tarihi, C. I, TTK Yayınları, Ankara 2011.

Ünal, Tahsin, Karamanoğullan Tarihi, Berikan Yayınları, Ankara 2007.

Yörük, Doğan, "Selçuklu'dan Osmanlı'ya Konya'da Vakıf Kuran Kadınlar”, Geçmişten Günümüze Şehir ve Kadın I, (Edit. Osman Köse), Samsun 2016, ss. 475488. 
